J. Dairy Sci. 92:270-285

doi:10.3168/jds.2008-1432

(C) American Dairy Science Association, 2009.

\title{
Interaction of molasses and monensin in alfalfa hay- or corn silage-based diets on rumen fermentation, total tract digestibility, and milk production by Holstein cows ${ }^{1}$
}

\author{
E. R. Oelker, C. Reveneau, and J. L. Firkins ${ }^{2}$ \\ Department of Animal Sciences, The Ohio State University, Columbus 43210
}

\begin{abstract}
Sugar supplementation can stimulate rumen microbial growth and possibly fiber digestibility; however, excess ruminal carbohydrate availability relative to rumen-degradable protein (RDP) can promote energy spilling by microbes, decrease rumen $\mathrm{pH}$, or depress fiber digestibility. Both RDP supply and rumen $\mathrm{pH}$ might be altered by forage source and monensin. Therefore, the objective of this study was to evaluate interactions of a sugar source (molasses) with monensin and 2 forage sources on rumen fermentation, total tract digestibility, and production and fatty acid composition of milk. Seven ruminally cannulated lactating Holstein cows were used in a $5 \times 7$ incomplete Latin square design with five 28-d periods. Four corn silage diets consisted of 1) control (C), 2) $2.6 \%$ molasses (M), 3) $2.6 \%$ molasses plus $0.45 \%$ urea (MU), or 4) $2.6 \%$ molasses plus $0.45 \%$ urea plus monensin sodium (Rumensin, at the intermediate dosage from the label, $16 \mathrm{~g} / 909 \mathrm{~kg}$ of dry matter; MUR). Three chopped alfalfa hay diets consisted of 1) control (C), 2) $2.6 \%$ molasses (M), or 3) $2.6 \%$ molasses plus Rumensin (MR). Urea was added to corn silage diets to provide RDP comparable to alfalfa hay diets with no urea. Corn silage $\mathrm{C}$ and $\mathrm{M}$ diets were balanced to have $16.2 \%$ crude protein; and the remaining diets, $17.2 \%$ crude protein. Dry matter intake was not affected by treatment, but there was a trend for lower milk production in alfalfa hay diets compared with corn silage diets. Despite increased total volatile fatty acid and acetate concentrations in the rumen, total tract organic matter digestibility was lower for alfalfa hay-fed cows. Rumensin did not affect volatile
\end{abstract}

\footnotetext{
Received June 6, 2008.

Accepted September 3, 2008.

${ }^{1}$ Salaries and research support were provided by state and federal funds appropriated to the Ohio Agricultural Research and Development Center, The Ohio State University. Contributing to Regional Research Project NC-1009. Manuscript No. 35/07AS. Additional research support provided by Quality Liquid Feeds (Dodgeville, WI) and Elanco Animal Health (Greenfield, IN).

${ }^{2}$ Corresponding author: firkins.1@osu.edu
}

fatty acid concentrations but decreased milk fat from 3.22 to $2.72 \%$ in corn silage diets but less in alfalfa hay diets. Medium-chain milk fatty acids (\% of total fat) were lower for alfalfa hay compared with corn silage diets, and short-chain milk fatty acids tended to decrease when Rumensin was added. In whole rumen contents, concentrations of trans-10, cis-12 $\mathrm{C}_{18: 2}$ were increased when cows were fed corn silage diets. Rumensin had no effect on conjugated linoleic acid isomers in either milk or rumen contents but tended to increase the concentration of trans-10 $\mathrm{C}_{18: 1}$ in rumen samples. Molasses with urea increased ruminal $\mathrm{NH}_{3}-\mathrm{N}$ and milk urea $\mathrm{N}$ when cows were fed corn silage diets (6.8 vs. 11.3 and 7.6 vs. $12.0 \mathrm{mg} / \mathrm{dL}$ for M vs. MU, respectively). Based on ruminal fermentation characteristics and fatty acid isomers in milk, molasses did not appear to promote ruminal acidosis or milk fat depression. However, combinations of Rumensin with corn silage-based diets already containing molasses and with a relatively high nonfiber carbohydrate:forage neutral detergent fiber ratio influenced biohydrogenation characteristics that are indicators of increased risk for milk fat depression. Key words: molasses, monensin, milk fat production

\section{INTRODUCTION}

Sugar-containing liquid feeds can increase the energy density of the diet, stimulate DMI, and serve as carriers for fat, NPN, and other ingredients. Sugars can change the ruminal fermentation pattern, typically decreasing ruminal $\mathrm{NH}_{3}$ concentration (Broderick and Radloff, 2004; DeFrain et al., 2006) and increasing ruminal butyrate concentration (Hristov and Ropp, 2003; DeFrain et al., 2004, 2006). Rapid fermentation of sugars could lead to lactic acid accumulation (if not converted to butyrate or propionate), and decreased ruminal $\mathrm{pH}$ could depress fiber digestibility. Therefore, many dose responses of molasses were quadratic in 2 trials (Broderick and Radloff, 2004), and response to liquid feeds containing molasses tended to be optimized with dilution of dietary NFC (Firkins et al., 2008b).

Some of the variability in response to sugars likely depends on the source of forage, which varies in com- 
position of NSC and in RDP. For example, corn silage contains high-moisture corn grain, which has a high ruminal NSC digestibility and has a greater percentage of NFC (the by-difference calculation) in the form of starch compared with alfalfa (Firkins et al., 2001). Excessive carbohydrate compared with RDP supply could promote energy spilling by rumen microbes (Russell, 1998), and alfalfa hay has more RDP than corn silage (NRC, 2001). Monensin might alleviate effects of rapid sugar fermentation by inhibiting lactic acid-producing bacteria and could decrease deamination (Firkins et al., 2006). Maia et al. (2007) noted that the presence of lactate $(70 \mathrm{mM})$ influenced the sensitivity toward linoleic acid's inhibition of pure cultures of biohydrogenating bacteria. Although not fully known which fatty acid (FA) intermediates of biohydrogenation are associated with milk fat depression (Shingfield et al., 2006), the relevance to dairy production has been well described (Jenkins and McGuire, 2006). The NFC and forage NDF concentrations were more prominently associated with milk fat production than was particle size of corn silage-based diets when compared with grass silagebased diets (Tafaj et al., 2007). Thus, feeding sugars might increase the accumulation of lactate and, correspondingly, FA isomers that depress milk fat secretion more in diets based on corn silage than on alfalfa hay as forage sources. However, monensin could promote milk fat depression when combined with dietary unsaturated fat and high ruminal carbohydrate fermentability (Firkins et al., 2006).

The objectives were to test the hypotheses that 1) molasses in combination with Rumensin would depress milk fat production in diets based on corn silage more compared with alfalfa and 2) molasses would decrease RDP supply below requirements and limit NDF digestibility more in corn silage-based diets without urea than with urea. To test these hypotheses, we measured 1) lactation performance, 2) total tract nutrient digestibility, 3) rumen fermentation patterns, and 4) milk FA composition in dairy cows fed diets containing corn silage or alfalfa hay as forages and supplemented with molasses, urea (only to corn silage diets), and Rumensin.

\section{MATERIALS AND METHODS}

\section{Animals, Treatments, and Experimental Design}

Seven rumen-cannulated lactating Holstein cows were used. Care and handling of the animals were conducted as outlined in the guidelines of The Ohio State University Institutional Animal Care and Use Committee. At the start of the experiment, cows were $132 \pm 37$ DIM. Cows were housed in a tie-stall barn. They were milked at 0430 and $1630 \mathrm{~h}$, with time to exercise before the afternoon milking (about $1 \mathrm{~h}$ ). They had free access to water at all times.

The experimental design was a $5 \times 7$ incomplete Latin square with 7 cows and 5 periods. Within periods, 3 wk were used to adjust cows to their respective diets, and the fourth week was for sample collection. Diets contained either alfalfa hay or corn silage as the sole forage (Table 1). The liquid feed used in this trial was a blend of molasses, condensed corn steep liquor, and condensed whey (Dairy Sugr 38, Quality Liquid Feeds, Dodgeville, WI), hereafter referred to as molasses after its main component. There were 4 diets with corn silage: 1) control (C), 2) $2.6 \%$ molasses (M), 3) $2.6 \%$ molasses plus $0.45 \%$ urea (MU), and 4) $2.6 \%$ molasses plus $0.45 \%$ urea plus monensin in the form of Rumensin (Elanco Animal Health, Greenfield, IN; $16 \mathrm{~g} / 909 \mathrm{~kg}$ of DM; MUR). Three alfalfa hay diets were: 1) control (C), 2) $2.6 \%$ molasses (M), and 3) $2.6 \%$ molasses plus Rumensin (16 g/909 kg; MR). Batches of molassescontaining liquid feeds were analyzed to contain 58.6 $\pm 1.5 \%$ invert sugars by the provider (Quality Liquid Feeds). The corn silage $\mathrm{C}$ and $\mathrm{M}$ and the alfalfa hay $\mathrm{C}, \mathrm{M}$, and MR diets were balanced to provide $16.2 \%$ $\mathrm{CP}$. The corn silage $\mathrm{C}$ diet was at $101 \%$ of RDP requirements $(10.2 \%$ RDP based on the NRC feed library except that feeds were corrected for their actual CP), whereas the alfalfa hay $\mathrm{C}$ diet was about $113 \%$ of the $\mathrm{RDP}$ requirement $(11.2 \% \mathrm{RDP})$ for a $682-\mathrm{kg}$ cow eating $22.7 \mathrm{~kg} / \mathrm{d}$ of DMI and producing $36.4 \mathrm{~kg} / \mathrm{d}$ of milk with $3.5 \%$ fat according to the NRC (2001) model. The corn silage $\mathrm{M}$ diet was projected to decrease ruminal $\mathrm{NH}_{3} \mathrm{~N}$ concentration below optimum, so the corn silage MU and MUR diets were balanced to provide $17.2 \% \mathrm{CP}$ and the same RDP as the alfalfa hay M and MR. The forage NDF and NFC portions were balanced to be 18.0 and $41.0 \%$, respectively.

Diets were individually mixed as a TMR once but fed twice daily. Alfalfa hay was added to a TMR mixer wagon to decrease particle size and unloaded after processing. Water $(6.0 \mathrm{~kg})$ was added daily to each hay diet while mixing in a stationary ribbon mixer to improve cow acceptance. Molasses was added after the other ingredients had mixed and was allowed to mix until it was visibly distributed throughout the TMR. Rumensin was included at one-half of the daily dose for $3 \mathrm{~d}$ before switching to the full dose. The DM of forages was determined weekly, and the diets were adjusted accordingly. Cows were fed at ad libitum, and refusal was kept to $5 \%$ during the first $3 \mathrm{wk}$ of each period. Because cows might sort more hay than corn silage (Leonardi and Armentano, 2003), refusal was kept to 3\% during wk 4 to ensure that actual daily consumption reflected the formulated diets. 
Table 1. Ingredient composition (\% of DM) of experimental diets

\begin{tabular}{|c|c|c|c|c|c|c|c|}
\hline Ingredient & \multicolumn{4}{|c|}{ Corn silage $^{1}$} & \multicolumn{3}{|c|}{ Alfalfa hay ${ }^{1}$} \\
\hline Corn silage & 43.9 & 43.9 & 43.9 & 43.9 & - & - & - \\
\hline Molasses & - & 2.64 & 2.64 & 2.64 & - & 2.64 & 2.64 \\
\hline Urea & - & - & 0.45 & 0.45 & - & - & - \\
\hline Soybean meal, $48 \% \mathrm{CP}$ & 12.1 & 12.1 & 12.1 & 12.1 & - & - & - \\
\hline Soybean hulls & 15.5 & 15.5 & 13.2 & 13.2 & 11.9 & 11.9 & 11.9 \\
\hline Corn grain, ground & 18.4 & 15.8 & 17.7 & 17.7 & 28.5 & 25.9 & 25.9 \\
\hline Minerals + vitamins & 2.09 & 2.09 & 2.09 & 2.09 & 1.18 & 1.18 & 1.18 \\
\hline Rumensin premix & - & - & - & 0.01 & - & - & 0.01 \\
\hline
\end{tabular}

${ }^{1} \mathrm{C}=$ control; $\mathrm{M}=$ control plus molasses; $\mathrm{MU}=$ control with molasses and urea; $\mathrm{MUR}=$ control with molasses, urea. and Rumensin; MR = control with molasses and Rumensin. The molasses-containing product was Dairy Sugr 38 (Quality Liquid Feeds, Dodgeville, WI), which also contained corn steep liquor and condensed whey. Rumensin premix (Elanco Animal Health, Greenfield, IN) had $36.4 \mathrm{~g}$ of monensin/kg and was included at the label rate of $16 \mathrm{~g} / 909 \mathrm{~kg}$ of $\mathrm{DM}$ in the total diet.

\section{Sample Schedule}

The TMR was sampled once daily on d 23 through 26 and was composited by period. Ten percent of the refusal was sampled daily on d 24 through 27, frozen, and composited by period. On d 26 and 27, TMR were sampled at 0,2 , and $8 \mathrm{~h}$ after feeding for particle size analyses. Starting on d 18 through the rest of the period, pellets containing 95\% soybean hulls and 5\% $\mathrm{Cr}_{2} \mathrm{O}_{3}$ were dosed via the rumen cannula twice daily at $2 \%$ of the average DMI determined during the first 2 wk of the period. Fecal grab samples were taken twice per day on d 24 through 27 to represent every $1.5 \mathrm{~h}$ of a $12-\mathrm{h}$ period between feedings. Fecal samples were dried and composited by weight at the end of each period.

The NDF disappearance in situ was determined on d 24 through 28. Samples of alfalfa hay and corn silage were ground through a 2 -mm screen, and $3 \mathrm{~g}$ was weighed into polyethylene terephthalate bags $(10 \mathrm{~cm} \times$ $20 \mathrm{~cm} ; 50-\mu \mathrm{m}$ pore size). Bags were inserted into the rumen of cows fed the respective forages and removed at $2,4,8,12,24,48$, and $96 \mathrm{~h}$. After washing in cold tap water until the rinse water was clear, the bags were dried in a forced-air oven for $48 \mathrm{~h}$ at $55^{\circ} \mathrm{C}$ for determination of kinetics of NDF disappearance (Reveneau et al., 2005).

Ruminal samples $(500 \mathrm{~mL})$ were taken on d 25 at 0 , 3,6 , and $9 \mathrm{~h}$ after the a.m. feeding. Whole ruminal contents $(200 \mathrm{~g})$ were subsampled and frozen until further analysis. A second subsample of rumen contents was squeezed through 4 layers of cheesecloth, and the $\mathrm{pH}$ was recorded immediately before acidification of 100 mL with $6 \mathrm{~mL}$ of $6 \mathrm{~N} \mathrm{HCl}$ and freezing until further analysis. An additional $25 \mathrm{~mL}$ of fluid was fixed with $25 \mathrm{~mL}$ of $50 \%$ formalin and stored at room temperature to preserve protozoa. Squeezed solids from the second subsample $(200 \mathrm{~g})$ were washed with $0.9 \%$ saline and squeezed again through 4 layers of cheesecloth. Solids retained in the cheesecloth were blended with $200 \mathrm{~mL}$ of $0.9 \%$ saline for $45 \mathrm{~s}$ and frozen before preparation of particle-associated bacteria by differential centrifugation (Piwonka et al., 1994) after which samples were frozen again.

During the collection period, milk yield was recorded daily by computer. Milk samples were taken from 4 consecutive milkings. One aliquot of each milk sample was analyzed by infrared procedures for fat, true protein, lactose, and MUN by DHI Cooperative Inc. (Columbus, $\mathrm{OH})$. Another aliquot was analyzed for FA composition. The BCS was determined at the beginning of the first period and at the end of each period throughout the trial. Body weight was measured weekly after the afternoon milking.

\section{Laboratory Analysis}

The TMR and refusals were dried and ground to pass a 2-mm screen. Samples were analyzed for ash, DM, and N (AOAC, 1990). Samples were also analyzed for NDF, ADF, and acid detergent lignin (ADL) according to Van Soest et al. (1991). The NDF was determined using amylase and sodium sulfite with pretreatment of acetone. After an acetone pretreatment of a separate sample, ADF was determined, and ADL was analyzed from the ADF residue. All fiber values were reported without ash correction. Dried $\left(55^{\circ} \mathrm{C}\right)$ samples of TMR and refusals at 2 and $8 \mathrm{~h}$ were separated using the Penn State TMR Particle Separator according to the directions of the manufacturer. The particle size of dried forage samples also was determined by mechani- 
cal shaking with a portable sieve shaker (W. S. Tyler Inc., Gastonia, NC) for 5 min through 6 sieves with pore sizes of $9.5,4.75,2.36,1.18,0.60$, and $0.30 \mathrm{~mm}$ per square side. A log-normal distribution was assumed (Murphy and Zhu, 1997). Using Excel, the NORMINV function (mean $=0 ; \mathrm{SD}=1$ ) of the cumulative proportions of DM retained on each screen or larger were plotted against the logarithms (base 10) of screen size. From the linear regression, solving for $\mathrm{y}=0$ provided the log of the mean particle size; the SD was the inverse of the slope.

Whole rumen contents were subsampled, freezedried, and ground to pass a 2-mm screen. Fatty acids in whole rumen contents and milk were methylated in 2 steps with $2 \mathrm{~mL}$ of $0.5 \mathrm{M}$ sodium methoxide $(10 \mathrm{~min}$ at $\left.50^{\circ} \mathrm{C}\right)$, followed by $3 \mathrm{~mL}$ of $5 \%$ methanolic $\mathrm{HCl}(10 \mathrm{~min}$ at $80^{\circ} \mathrm{C}$ ). Fatty acid isomers were separated by GLC according to Reveneau et al. (2005) except that the GLC was equipped with a fused silica capillary column (SP-2560; 100-m length, 0.25-mm i.d., and 0.2- $\mu \mathrm{m}$ film thickness; Supelco Inc., Bellefonte, PA). Samples of composited TMR and feed refusals were analyzed for FA concentrations using the 1-step methylation method of Palmquist and Jenkins (2003).

Rumen fluid samples were thawed to room temperature and centrifuged at $15,000 \times g$ for $20 \mathrm{~min}$. The supernatant was filtered through Whatman no. 1 filter paper (Whatman International, Maidstone, UK) into sample bottles. Samples were analyzed for $\mathrm{NH}_{3} \mathrm{~N}$ (Chaney and Marbach, 1962). These samples were used for analysis of VFA according to Harvatine et al. (2002). Additionally, L-lactate was determined with a kit for a colorimetric procedure utilizing lactate oxidase (Pointe Scientific Inc., Canton, MI). The L isomers likely predominate in the rumen unless $\mathrm{pH}$ decreases (Nagaraja and Titgemeyer, 2007); however, ignoring the D isomers marginally underrepresents the total lactate.

Activities of carboxymethyl cellulase (CMCase) and xylanase (using birchwood xylan) were determined on solids-associated bacteria (Reveneau et al., 2003), standardizing for protein concentration using a bicinchoninic acid protein assay kit (Pierce, Rockford, IL), and frozen again for subsequent analysis of enzymatic activity. Fecal samples were ground to pass a 2-mm screen and analyzed as described previously for DM, OM, N, and NDF. Fecal samples and chromic oxide pellets were analyzed for Cr by atomic absorption (Williams et al., 1962) for estimation of apparent total tract digestibility.

\section{Statistical Analysis}

Statistical analysis was conducted using the following model

Table 2. Chemical composition of experimental diets

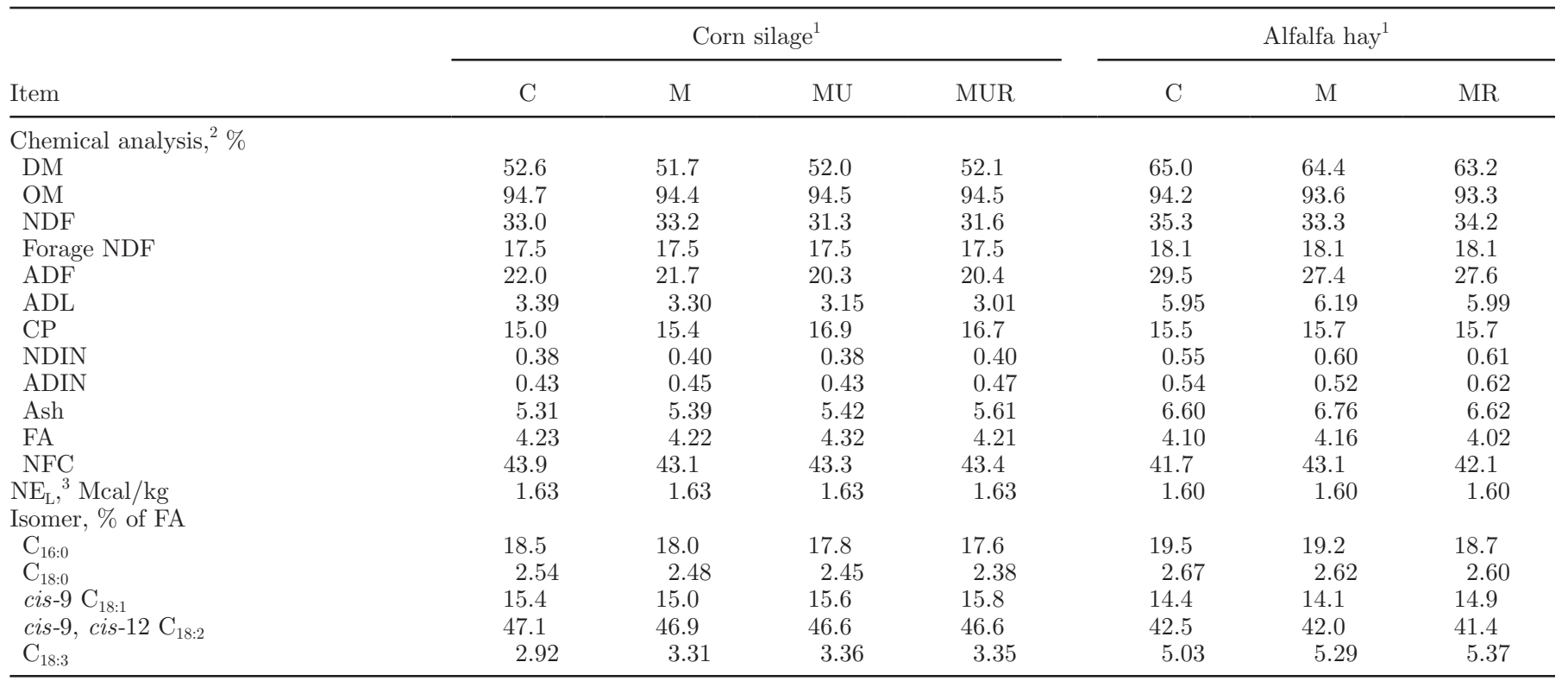

${ }^{1} \mathrm{C}=$ control; $\mathrm{M}=$ control plus molasses; $\mathrm{MU}=$ control with molasses and urea; $\mathrm{MUR}=$ control with molasses, urea, and Rumensin (Elanco Animal Health, Greenfield, IN); MR = control with molasses and Rumensin. The molasses-containing product also had a blend of corn steep liquor and condensed whey. Rumensin diets provided $16 \mathrm{~g}$ of monensin/909 $\mathrm{kg}$ of DM.

${ }^{2} \mathrm{ADL}=$ acid detergent lignin; $\mathrm{NDIN}=$ neutral detergent insoluble $\mathrm{N} ; \mathrm{FA}=$ fatty acids; $\mathrm{NFC}=[\mathrm{OM}-\mathrm{NDF}-\mathrm{CP}-(\mathrm{FA}+1)+(\mathrm{NDIN} \times$ $6.25)]$. All are percentages of DM except for DM (\% of as is).

${ }^{3}$ The $\mathrm{NE}_{\mathrm{L}}$ was calculated from NRC (2001). 


$$
\mathrm{Y}_{\mathrm{ijkl}}=\mu+\mathrm{c}_{\mathrm{i}}+\mathrm{P}_{\mathrm{j}}+\mathrm{D}_{\mathrm{k}}+\mathrm{T}_{\mathrm{l}}+\mathrm{TD}_{\mathrm{kl}}+\mathrm{e}_{\mathrm{ijk} \mathrm{k}},
$$

where $\mu=$ the overall mean; $\mathrm{c}=$ the random effect of cow $(\mathrm{i}=1,2, \ldots 7) ; \mathrm{P}=$ the fixed effect of period $(\mathrm{j}$ $=1,2, \ldots 5) ; \mathrm{D}=$ the fixed effect of $\operatorname{diet}(\mathrm{k}=1,2, \ldots$ . 7); $\mathrm{T}=$ the fixed effect of time, included for repeated measures $(1=0,3,6,9)$; $\mathrm{TD}=$ the interaction of diet and time, included for repeated measures; and $\mathrm{e}=$ the residual error.

Repeated measures were done for rumen measurements, and the most appropriate covariance structure was determined by Bayesian information criterion. The NDF degradation kinetics were analyzed with PROC NLIN of SAS (version 9, SAS Institute, Cary, NC). The resulting parameter estimates and all other data were analyzed by PROC MIXED of SAS.

All interactions were $P>0.15$. Treatment sums of squares were partitioned into the following contrasts: 1) main effect of molasses: corn silage $C+$ alfalfa hay $\mathrm{C}$ vs. corn silage $\mathrm{MU}+$ alfalfa hay $\mathrm{M}, 2$ ) interaction of forage and molasses: corn silage $\mathrm{C}+$ alfalfa hay $\mathrm{M}$ vs. corn silage MU + alfalfa hay C, 3) main effect of forage: corn silage MU + MUR vs. alfalfa hay $\mathrm{M}+\mathrm{MR}, 4)$ main effect of Rumensin: corn silage MU + alfalfa hay M vs. corn silage MUR + alfalfa hay MR, 5) interaction of forage and Rumensin: corn silage MU + alfalfa hay MR vs. corn silage MUR + alfalfa hay M, and 6) urea effect in corn silage diets: corn silage $\mathrm{M}$ vs. corn silage MU.

In the first contrast (corn silage $\mathrm{C}+$ alfalfa hay $\mathrm{C}$ vs. corn silage $\mathrm{MU}+$ alfalfa hay $\mathrm{M}$ ), corn silage $\mathrm{MU}$ was chosen to represent the effect of molasses as an energy source instead of the corn silage $\mathrm{M}$ diet based on a priori expectations that 1) molasses would decrease the concentration of $\mathrm{NH}_{3}-\mathrm{N}$ to be below concentrations limiting microbial growth and 2) corn silage MU was formulated to have the same RDP concentration as the alfalfa $\mathrm{M}$ diet. Compared with the corn silage $\mathrm{C}$ diet, the corn silage $\mathrm{M}$ diet would have included both the effects of added molasses plus the response from limiting $\mathrm{NH}_{3}$, so the MU diet was chosen to represent the effect of adding molasses as an energy source to corn silage diets for all comparisons without potential confounding effects from RDP limitation. The comparison of corn silage $\mathrm{M}$ to $\mathrm{MU}$ was expected to test the response to potential $\mathrm{NH}_{3}-\mathrm{N}$ limitation when $\mathrm{M}$ was added.

\section{RESULTS AND DISCUSSION}

The dosage rate of monensin (16 g/909 $\mathrm{kg}$ of DM) was confirmed by laboratory analysis (Elanco Animal Health; data not shown). Alfalfa hay diets had slightly higher DM percentage than corn silage diets even with the addition of water to soften the hay (Table 2). Con- centration of NDF was higher in the control diets of both corn silage and alfalfa hay, because molasses addition diluted some nonforage NDF. The NDF percentage was 2 units lower in corn silage diets MU and MUR, probably because of the removal of soybean hulls that accompanied the addition of urea. As planned, there was an average of $1.52 \%$ added sugar to the corn silage $\mathrm{M}, \mathrm{MU}$, and MUR diets and the alfalfa hay M and MR diets (data not shown). Corn silage diets had lower concentrations of linolenic acid and higher concentrations of linoleic acid than hay diets, which is consistent with the concentrations of these FA in corn silage (Table $3)$.

\section{Particle Size and Sorting}

Geometric mean particle sizes were $3.7(\mathrm{SD}=0.45)$ and $3.5(\mathrm{SD}=0.67) \mathrm{mm}$ for corn silage and alfalfa hay, respectively (Table 3 ). Using the Penn State shaker, there were no treatment $\times$ time interactions $(P>0.15)$, so main effect means are presented for the total diets averaged over the 0,2 , and $8 \mathrm{~h}$ after feeding (Table 4). In agreement with a wider SD for alfalfa hay from the dry-sieving technique, the main effect of forage $(P$ $<0.01)$ is explained by there being a greater $(P<$ 0.01 ) percentage of particles larger than $19 \mathrm{~mm}$ and smaller than $8 \mathrm{~mm}$ (in the bottom pan) in the alfalfa hay diets compared with corn silage diets, which had a correspondingly greater percentage of particles retained

Table 3. Chemical composition of forages

\begin{tabular}{lcc}
\hline Item $^{1}$ & Corn silage & Alfalfa hay \\
\hline $\mathrm{DM}$ & 31.8 & 76.2 \\
$\mathrm{OM}$ & 96.5 & 91.9 \\
$\mathrm{NDF}$ & 39.8 & 42.0 \\
$\mathrm{ADF}$ & 23.2 & 35.5 \\
$\mathrm{ADL}$ & 3.03 & 7.44 \\
$\mathrm{CP}$ & 6.16 & 16.5 \\
$\mathrm{Ash}$ & 3.51 & 8.14 \\
$\mathrm{FA}$ & 2.01 & 1.73 \\
Particle size, ${ }^{2} \mathrm{~mm}$ & 3.65 & 3.51 \\
FA, ${ }^{3}$ g/100 g of FA & & \\
$\mathrm{C}_{16: 0}$ & 9.91 & 15.0 \\
$\mathrm{C}_{18: 0}$ & 1.54 & 2.58 \\
cis- $^{-} \mathrm{C}_{18: 1}$ & 10.2 & 2.44 \\
$\mathrm{C}_{18: 2}$ & 49.5 & 34.7 \\
$\mathrm{C}_{18: 3}$ & 4.48 & 13.7 \\
SCFA & 20.1 & 13.9 \\
MCFA & 11.1 & 19.1 \\
LCFA & 0.81 & 11.7 \\
\hline
\end{tabular}

${ }^{1} \mathrm{ADL}=$ acid detergent lignin; $\mathrm{FA}=$ fatty acids.

${ }^{2}$ Mean particle size by dry-sieving based on a log-normal distribution. The SD averaged 0.45 and 0.67 for corn silage and alfalfa hay, respectively.

${ }^{3} \mathrm{SCFA}=$ short-chain fatty acids $\left(\mathrm{C}_{4}\right.$ to $\left.\mathrm{C}_{13}\right) ; \mathrm{MCFA}=$ mediumchain fatty acids $\left(\mathrm{C}_{14}\right.$ to $\left.\mathrm{C}_{17: 1}\right)$; LCFA $=$ long-chain fatty acids $\left(\mathrm{C}_{20}\right.$ to $\mathrm{C}_{22: 6}$ ). 
Table 4. Least squares means of particle size distribution of diets by cows fed molasses, urea, and monensin with either alfalfa hay or corn silage as a forage source ${ }^{1}$

\begin{tabular}{|c|c|c|c|c|c|c|c|c|c|c|c|c|c|c|}
\hline \multirow[b]{2}{*}{ Screen } & \multicolumn{4}{|c|}{ Corn silage $^{2}$} & \multicolumn{3}{|c|}{ Alfalfa hay $^{2}$} & \multirow[b]{2}{*}{ SEM } & \multicolumn{6}{|c|}{ Contrast $^{3}$} \\
\hline & $\mathrm{C}$ & M & $\mathrm{MU}$ & MUR & $\mathrm{C}$ & $\mathrm{M}$ & MR & & F & M & $\mathrm{M} \times \mathrm{F}$ & $\mathrm{U}$ & $\mathrm{R}$ & $\mathrm{R} \times \mathrm{F}$ \\
\hline Middle, $8 \mathrm{~mm}$ & 45.6 & 53.7 & 57.3 & 55.8 & 23.6 & 21.1 & 26.0 & 3.2 & $<0.01$ & NS & 0.03 & NS & NS & NS \\
\hline Bottom pan & 50.1 & 42.5 & 38.6 & 40.5 & 56.9 & 59.1 & 48.2 & 2.8 & $<0.01$ & 0.09 & 0.01 & NS & NS & 0.03 \\
\hline
\end{tabular}

${ }^{1}$ No diet $\times$ time interactions $(P>0.15)$; therefore, least squares means for particles from the Penn State shaker were averaged over 0,2 , and 8 $\mathrm{h}$ after feeding.

${ }^{2} \mathrm{C}=$ control; $\mathrm{M}=$ control plus molasses; $\mathrm{MU}=$ control with molasses and urea; $\mathrm{MUR}=$ control with molasses, urea, and Rumensin; $\mathrm{MR}=$ control with molasses and Rumensin (Elanco Animal Health, Greenfield, IN). The molasses-containing product also had a blend of corn steep liquor and condensed whey. Rumensin diets provided $16 \mathrm{~g}$ of monensin $/ 909 \mathrm{~kg}$ of DM.

${ }^{3} \mathrm{U}=$ effect of urea (M vs. MU in CS); $\mathrm{M}=$ effect of molasses $(\mathrm{C}$ diets vs. $\mathrm{MU}$ in $\mathrm{CS}+\mathrm{M}$ in $\mathrm{AH}) ; \mathrm{M} \times \mathrm{F}=$ molasses $\times$ forage interaction $(\mathrm{C}$ in $\mathrm{CS}+\mathrm{M}$ in $\mathrm{AH}$ vs. $\mathrm{MU}$ in $\mathrm{CS}+\mathrm{C}$ in $\mathrm{AH}) ; \mathrm{F}=$ effect of forage source (MU + MUR in CS vs. $\mathrm{M}+\mathrm{MR}$ in $\mathrm{AH}) ; \mathrm{R}=\mathrm{effect}$ of Rumensin (MU in $\mathrm{CS}+\mathrm{M}$ in $\mathrm{AH}$ vs. MUR in $\mathrm{CS}+\mathrm{MR}$ in $\mathrm{AH}) ; \mathrm{R} \times \mathrm{F}=$ Rumensin $\times$ forage interaction $(\mathrm{MU}$ in $\mathrm{CS}+\mathrm{MR}$ in $\mathrm{AH}$ vs. MUR in CS $+\mathrm{M}$ in $\mathrm{AH})$, where $\mathrm{CS}=$ corn silage diets and $\mathrm{AH}=$ alfalfa hay diets.

${ }^{4} \mathrm{NS}=$ not significant $(P>0.15)$.

on the 8 -mm sieve. Molasses $\times$ forage interactions are mainly explained by a greater percentage of particles on the 8 -mm screen, with a lower percentage in the pan. These effects were just as prominent at $0 \mathrm{~h}$ as at $8 \mathrm{~h}$ (data not shown). Supporting field observations, molasses probably conglomerated smaller particles with corn silage diets but not with alfalfa hay diets. Water was added to the diets before molasses, and this procedure might have decreased the ability of molasses to conglomerate smaller particles to the outside surface of larger hay particles, or more molasses might be needed in such circumstances. Additionally, there were significant Rumensin $\times$ forage source interactions in which alfalfa hay diets had a greater percentage of particles greater than $19 \mathrm{~mm}(P=0.09)$ and less than $8 \mathrm{~mm}(P$ $=0.03$ ), although the reason for this effect is unclear. Over time and averaged over treatments (data not shown), the proportion of particles greater than $19 \mathrm{~mm}$ increased numerically $(P>0.15)$ from 9.8 to $14.8 \%$, particles greater than $8 \mathrm{~mm}$ decreased $(P<0.01)$ from 46.3 to $31.7 \%$, and particles less than $8 \mathrm{~mm}$ increased $(P<0.01)$ from 43.9 to $53.9 \%$. Our individually fed cows must have sorted against the largest and smallest particles in the diet in favor of particles between 19 and $8 \mathrm{~mm}$ in size. Similarly, cows sorted against long forages particularly when they were fed diets with $51 \%$ forage compared with $62 \%$ forage (DeVries et al., 2007). Given that molasses decreased sorting in corn silage diets, these results might be particularly beneficial for group-fed cows to consume TMR more uniformly between feedings. In support of this implication, the forage NDF and NFC:NDF ratio were more highly related to production of milk and milk fat than was particle size when TMR were composed of corn silage as the forage (Tafaj et al., 2007). In that meta-analysis, the relationships to particle size were more pronounced with diets based on grass silage as the forage compared with corn silage.

\section{Protozoal Counts}

The main effect mean for alfalfa hay treatments was lower than that for corn silage for total cell counts of protozoa. Much of this response can be related to a greater cell count for corn silage MU and MUR (Rumensin effect, $P<0.02$ ), which was also noted for the percentage of Epidinium (Rumensin $\times$ forage, $P<0.01$; Table 5). Although there was an approximate 2-percentage unit increase in Epidinium, the predominance of Entodinium species combined with the increase of about $10^{6}$ total cells (without a major change in distribution in corn silage diets) suggests that Entodinium also might have been responsible for the increase in total cells. Although the urea effect was $P>0.15$, the $\mathrm{M}$ contrast included the $\mathrm{C}$ vs. MU treatments in corn silage diets. Prior work often demonstrated increased protozoal numbers for urea vs. soybean meal (Dennis et al., 1983). These results were attributed to decreased competitiveness by AA-using bacteria compared with protozoa, which can satisfy AA requirements by consuming bacteria (Dennis et al., 1983; Dehority, 2003). However, a low-affinity glutamate dehydrogenase was more recently cloned from Entodinium caudatum (Newbold et al., 2005), so direct effects of urea combined with M cannot be ruled out. Epidinium and members of the family Diplodiniinae are important degraders of hemicellulose (Béra-Maillet et al., 2005), so perhaps the greater proportion of hemicellulose in corn silage NDF than in alfalfa NDF promoted growth of these protozoa.

Molasses increased the percentage of Entodinium in corn silage and decreased Entodinium in alfalfa hay diets 
Table 5. Least squares means of protozoa counts in rumen contents of dairy cows fed molasses, urea, and monensin with either alfalfa hay or corn silage as a forage source

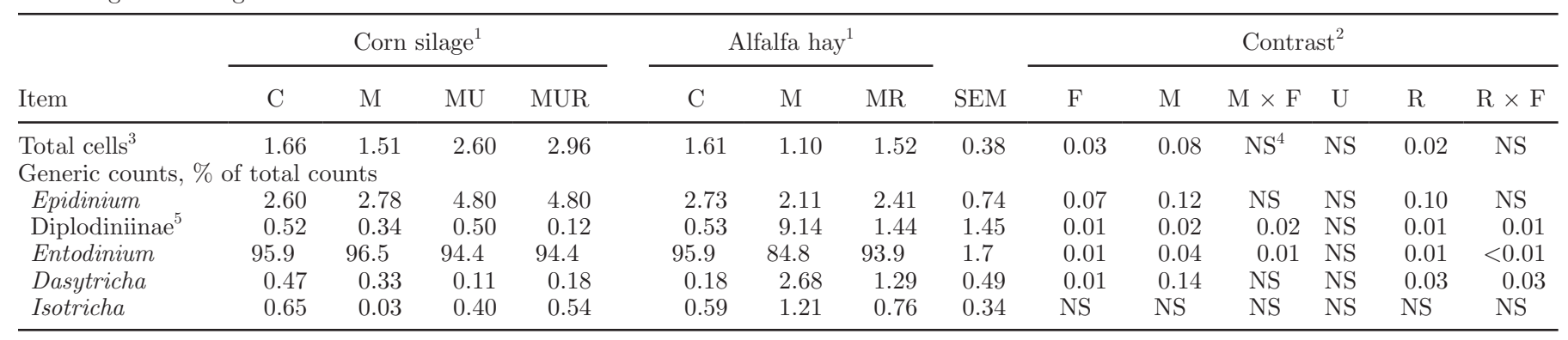

${ }^{1} \mathrm{C}=$ control; $\mathrm{M}=$ control plus molasses; $\mathrm{MU}=$ control with molasses and urea; $\mathrm{MUR}=$ control with molasses, urea, and Rumensin (Elanco Animal Health, Greenfield, IN); MR = control with molasses and Rumensin. The molasses-containing product also had a blend of corn steep liquor and condensed whey. Rumensin diets provided $16 \mathrm{~g}$ of monensin/909 $\mathrm{kg}$ of DM.

${ }^{2} \mathrm{U}=$ effect of urea ( $\mathrm{M}$ vs. $\mathrm{MU}$ in $\mathrm{CS}$ ); $\mathrm{M}=$ effect of molasses ( $\mathrm{C}$ diets vs. $\mathrm{MU}$ in $\mathrm{CS}+\mathrm{M}$ in $\mathrm{AH}$ ); $\mathrm{M} \times \mathrm{F}=$ molasses $\times$ forage interaction (C in $\mathrm{CS}+\mathrm{M}$ in $\mathrm{AH}$ vs. MU in $\mathrm{CS}+\mathrm{C}$ in $\mathrm{AH}) ; \mathrm{F}=$ effect of forage source $(\mathrm{MU}+\mathrm{MUR}$ in CS vs. $\mathrm{M}+\mathrm{MR}$ in $\mathrm{AH}) ; \mathrm{R}=$ effect of Rumensin $(\mathrm{MU}$ in $\mathrm{CS}+\mathrm{M}$ in $\mathrm{AH}$ vs. MUR in $\mathrm{CS}+\mathrm{MR}$ in $\mathrm{AH}) ; \mathrm{R} \times \mathrm{F}=$ Rumensin $\times$ forage interaction $(\mathrm{MU}$ in $\mathrm{CS}+\mathrm{MR}$ in $\mathrm{AH}$ vs. MUR in $\mathrm{CS}+\mathrm{M}$ in $\mathrm{AH})$, where $\mathrm{CS}=$ corn silage diets and $\mathrm{AH}=$ alfalfa hay diets.

${ }^{3}$ Total cells $/ \mathrm{mL}, \times 10^{6}$.

${ }^{4} \mathrm{NS}=$ not significant $(P>0.15)$.

${ }^{5}$ Subfamily consisting of the genera Diplodinium, Eudiplodinium, Ostracodinium, Metadinium, Enopoplastron, and Polyplastron.

(molasses $\times$ forage, $P<0.01$ ). Because the latter genus encompasses species with diverse ranges in cell size and niche (Dehority, 2003), the reason for this interaction is not clear. Cattle should have a diverse protozoal population unless excessive carbohydrate depresses ruminal $\mathrm{pH}$, in which case, the smaller Entodinium species are the most tolerant (Dehority, 2003). However, as seen in Table 6, treatment did not decrease ruminal pH. Entodiniomorphids can consume significant quantities of lactic acid (Brossard et al., 2004). Consequently, in the corn silage diets, some Entodinium species might have increased in abundance because more lactic acid might have been produced as an intermediate metabolite.

Contrasts for main effects and interactions for Diplodiniinae can be explained by an increase to over $9 \%$ of total protozoa in cows fed the alfalfa hay $\mathrm{M}$ diet, primarily at the expense of Entodinium. Both Diplodiniinae and Entodinium had the same contrast responses (especially Rumensin $\times$ forage interactions), with opposing distributions of the protozoal popula-

Table 6. Least squares means of fermentation characteristics for dairy cows fed molasses, urea, and monensin with either alfalfa hay or corn silage as a forage source

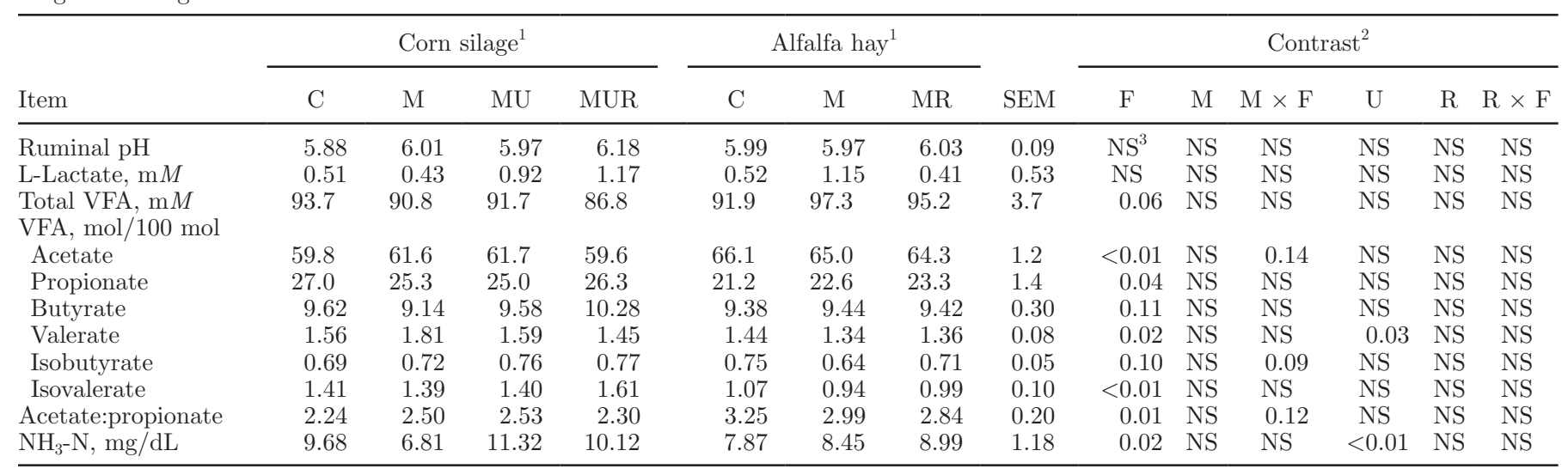

${ }^{1} \mathrm{C}=$ control; $\mathrm{M}=$ control plus molasses; $\mathrm{MU}=$ control with molasses and urea; $\mathrm{MUR}=$ control with molasses, urea, and Rumensin (Elanco Animal Health, Greenfield, IN); MR = control with molasses and Rumensin. The molasses-containing product also had a blend of corn steep liquor and condensed whey. Rumensin diets provided $16 \mathrm{~g}$ of monensin $/ 909 \mathrm{~kg}$ of DM.

${ }^{2} \mathrm{U}=$ effect of urea (M vs. $\mathrm{MU}$ in $\left.\mathrm{CS}\right) ; \mathrm{M}=$ effect of molasses $(\mathrm{C}$ diets vs. $\mathrm{MU}$ in $\mathrm{CS}+\mathrm{M}$ in $\mathrm{AH}) ; \mathrm{M} \times \mathrm{F}=$ molasses $\times$ forage interaction $(\mathrm{C}$ in $\mathrm{CS}+\mathrm{M}$ in $\mathrm{AH}$ vs. $\mathrm{MU}$ in $\mathrm{CS}+\mathrm{C}$ in $\mathrm{AH}) ; \mathrm{F}=$ effect of forage source $(\mathrm{MU}+\mathrm{MUR}$ in CS vs. $\mathrm{M}+\mathrm{MR}$ in $\mathrm{AH}) ; \mathrm{R}=$ effect of Rumensin $(\mathrm{MU}$ in $\mathrm{CS}+\mathrm{M}$ in $\mathrm{AH}$ vs. MUR in $\mathrm{CS}+\mathrm{MR}$ in $\mathrm{AH}) ; \mathrm{R} \times \mathrm{F}=$ Rumensin $\times$ forage interaction $(\mathrm{MU}$ in $\mathrm{CS}+\mathrm{MR}$ in $\mathrm{AH}$ vs. $\mathrm{MUR}$ in $\mathrm{CS}+\mathrm{M}$ in $\mathrm{AH})$, where $\mathrm{CS}=$ corn silage diets and $\mathrm{AH}=$ alfalfa hay diets.

${ }^{3} \mathrm{NS}=$ not significant, $P>0.15$. 
tion. Compared with many Entodinium species, many Diplodiniinae have a very large cell volume (Williams and Coleman, 1992). Total protozoal biomass, not cell numbers, should be regulated by substrate availability (Firkins et al., 2007; Sylvester et al., 2009).

Sugars diffuse past the permeable outer membrane of Diplodiniinae, waiting to be metabolized in the endoplasm (Williams and Coleman, 1992). Moreover, cell extracts from various Diplodiniinae had sucrase activities (Dehority, 2003). In contrast, Isotricha and Dasytricha species are regarded for their preference for sugars (Williams and Coleman, 1992), but these populations were not affected by molasses. Because Dasytricha was decreased by Rumensin but should be much less affected than other protozoa by even its abrupt introduction (Dennis et al., 1986), a direct effect of Rumensin does not seem likely. Consequently, our knowledge of protozoal ecology limits our ability to explain differences among treatments for protozoal cell counts.

\section{Ruminal Fermentation Characteristics}

Molasses did not change $(P>0.15)$ ruminal $\mathrm{pH}$, and no treatment $\times$ time interactions were observed (Table 6 ). Lactate concentration averaged $0.74 \mathrm{~m} M$, but no effect of treatment or treatment $\times$ time interactions was detected, and our low concentrations would be unlikely to influence ruminal pH. Broderick and Radloff (2004) fed 2.4 to $10.0 \%$ total sugars in their diets using either dried or liquid molasses, and DeFrain et al. (2004) fed either 5 or $13 \%$ lactose. Although neither report measured ruminal lactate, neither detected any effect on rumen $\mathrm{pH}$.

Compared with corn silage diets, feeding alfalfa hay increased total VFA concentration $(P<0.06)$ and acetate molar percentage $(P<0.01$; Table 6$)$. Broderick (1985) and Dhiman and Satter (1997) also observed an increase in acetate concentration when alfalfa hay or alfalfa silage, respectively, replaced corn silage, although they observed no overall change in total VFA concentrations. The main effect means for the alfalfa hay diets were lower $(P<0.04)$ for propionate and valerate molar percentages. Broderick (1985) also observed a decrease in propionate concentration with alfalfa hay diets. The increase in acetate:propionate for alfalfa hay also might be due, in part, to more coarse particles compared with corn silage (Table 4; Krause and Combs, 2003).

Molasses did not affect butyrate concentrations (Table 6). This lack of response is in stark contrast to several other studies with increased butyrate (Hristov and Ropp, 2003; DeFrain et al., 2004, 2006), perhaps from an increase in lactate metabolism to butyrate
(Firkins et al., 2007). The level of molasses inclusion (1.52\% added sugars) might not have been enough to evoke a response in the current study.

Urea addition decreased $(P<0.03)$ valerate molar percentage. Isobutyrate increased with molasses addition to corn silage diets and decreased when added to alfalfa hay diets (molasses $\times$ forage interaction; $P=$ 0.09). Although some studies have shown that sugars decrease branched-chain VFA concentrations (Firkins et al., 2007), no such effect was observed by Broderick and Radloff (2004). Isovalerate was decreased $(P<$ 0.01 ) when cows were fed alfalfa hay diets. Because alfalfa diets were formulated to have much greater RDP in peptide form than the corn silage diets (even with urea addition), the general decrease in branched-chain VFA and valerate concentrations could be associated with increased uptake by cellulolytic bacteria in cows fed alfalfa hay. Alfalfa hay has more cellulose (ADF minus ADL; Table 3) than corn silage, and cellulolytic bacteria require branched-chain VFA or valerate for growth (Dehority, 2003).

Consistent with other observations (Hristov and Ropp, 2003; Broderick and Radloff, 2004; DeFrain et al., 2006), molasses numerically decreased ruminal $\mathrm{NH}_{3}-\mathrm{N}$ concentration in corn silage diets (9.68 vs. 6.81 for corn silage $\mathrm{C}$ and $\mathrm{M}$, respectively; Table 6 ). The lack of an overall $\mathrm{M}$ contrast combined with the urea effect $(P$ $<0.01)$ in corn silage diets (6.81 vs. 11.32 for $\mathrm{M}$ and $\mathrm{MU}$, respectively) supports a direct effect of molasses. The urea effect had no consistent effects in subsequent measurements, so a benefit would only be likely when RDP was already at $101 \%$ of the predicted requirements of the NRC (2001) before addition of molasses. In alfalfa hay diets, molasses did not decrease $\mathrm{NH}_{3}-\mathrm{N}$. The forage effect indicates that urea addition to corn silage diets maintained a greater $\mathrm{NH}_{3}-\mathrm{N}$ concentration than the RDP from alfalfa hay.

Rumensin did not decrease the acetate:propionate ratio (Table 6), which is in contrast with expectations (McGuffey et al., 2001). The reason for our observed response from Rumensin is not entirely clear but is consistent with our other results (Firkins et al., 2008b).

\section{Nutrient Digestibility}

Alfalfa hay decreased $(P<0.01)$ the apparent total tract digestibilities of DM, OM, and N (Table 7). Similarly, Broderick (1985) observed that, in diets with the same percentage of NDF, alfalfa hay had lower DM digestibilities compared with a corn silage diet. Additionally, Hristov and Broderick (1996) reported that alfalfa hay decreased $\mathrm{DM}, \mathrm{OM}$, and $\mathrm{N}$ digestibilities. In their study, all-forage diets were fed and alfalfa hay 
Table 7. Least squares means of apparent nutrient digestibility in the total tract and fiber degradation kinetics for dairy cows fed molasses, urea, and monensin with either alfalfa hay or corn silage as a forage source

\begin{tabular}{|c|c|c|c|c|c|c|c|c|c|c|c|c|c|c|}
\hline \multirow[b]{2}{*}{ Item } & \multicolumn{4}{|c|}{ Corn silage $^{1}$} & \multicolumn{3}{|c|}{ Alfalfa hay ${ }^{1}$} & \multirow[b]{2}{*}{ SEM } & \multicolumn{6}{|c|}{ Contrast $^{2}$} \\
\hline & $\mathrm{C}$ & M & $\mathrm{MU}$ & MUR & $\mathrm{C}$ & M & MR & & $\mathrm{F}$ & $\mathrm{M}$ & $\mathrm{M} \times \mathrm{F}$ & $\mathrm{U}$ & $\mathrm{R}$ & $\mathrm{R} \times \mathrm{F}$ \\
\hline DM & 70.9 & 67.8 & 70.6 & 70.6 & 62.9 & 64.6 & 64.3 & 2.0 & $<0.01$ & $\mathrm{NS}^{3}$ & NS & NS & NS & NS \\
\hline $\mathrm{OM}$ & 75.6 & 70.1 & 71.8 & 72.8 & 63.5 & 65.6 & 66.2 & 2.4 & 0.01 & $\mathrm{NS}$ & NS & NS & NS & NS \\
\hline $\mathrm{NDF}$ & 53.5 & 47.3 & 50.5 & 48.5 & 42.7 & 44.4 & 42.5 & 4.5 & NS & $\mathrm{NS}$ & NS & NS & NS & NS \\
\hline $\mathrm{N}$ & 73.3 & 70.1 & 73.2 & 77.2 & 61.5 & 64.3 & 66.4 & 2.6 & $<0.01$ & NS & NS & NS & NS & NS \\
\hline Xylanase & 695 & 552 & 650 & 622 & 463 & 417 & 535 & 95 & 0.09 & NS & NS & NS & NS & NS \\
\hline \multicolumn{15}{|c|}{ NDF degradation in situ ${ }^{5}$} \\
\hline A, $\%$ & 8.07 & 5.20 & 4.75 & 8.60 & 5.17 & 4.27 & 3.70 & 1.75 & 0.08 & NS & NS & NS & NS & NS \\
\hline $\mathrm{B}, \%$ & 43.1 & 60.7 & 63.6 & 54.2 & 49.0 & 42.2 & 44.5 & 5.1 & $<0.01$ & NS & 0.01 & NS & NS & NS \\
\hline C, $\%$ & 48.7 & 34.8 & 31.6 & 37.2 & 46.0 & 53.5 & 51.9 & 5.3 & $<0.01$ & NS & 0.03 & NS & NS & NS \\
\hline $\mathrm{K}_{\mathrm{d}}, \% / \mathrm{h}$ & 2.58 & 2.98 & 2.37 & 4.02 & 5.18 & 5.40 & 5.40 & 0.01 & 0.01 & NS & NS & NS & NS & NS \\
\hline ERD, \% & 26.5 & 27.3 & 23.0 & 35.1 & 30.5 & 28.4 & 28.4 & 2.4 & NS & NS & NS & NS & 0.03 & 0.02 \\
\hline
\end{tabular}

${ }^{1} \mathrm{C}=$ control; $\mathrm{M}=$ control plus molasses; $\mathrm{MU}=$ control with molasses and urea; $\mathrm{MUR}=$ control with molasses, urea, and Rumensin (Elanco Animal Health, Greenfield, IN); MR = control with molasses and Rumensin. The molasses-containing product also had a blend of corn steep liquor and condensed whey. Rumensin diets provided $16 \mathrm{~g}$ of monensin/909 $\mathrm{kg}$ of DM.

${ }^{2} \mathrm{U}=$ effect of urea (M vs. $\mathrm{MU}$ in $\left.\mathrm{CS}\right) ; \mathrm{M}=$ effect of molasses $(\mathrm{C}$ diets vs. $\mathrm{MU}$ in $\mathrm{CS}+\mathrm{M}$ in $\mathrm{AH}) ; \mathrm{M} \times \mathrm{F}=$ molasses $\times$ forage interaction $(\mathrm{C}$ in $\mathrm{CS}+\mathrm{M}$ in $\mathrm{AH}$ vs. $\mathrm{MU}$ in $\mathrm{CS}+\mathrm{C}$ in $\mathrm{AH}) ; \mathrm{F}=$ effect of forage source (MU + MUR in CS vs. M + MR in AH); $\mathrm{R}=$ effect of Rumensin (MU in $\mathrm{CS}+\mathrm{M}$ in $\mathrm{AH}$ vs. MUR in $\mathrm{CS}+\mathrm{MR}$ in $\mathrm{AH}) ; \mathrm{R} \times \mathrm{F}=$ Rumensin $\times$ forage interaction $(\mathrm{MU}$ in $\mathrm{CS}+\mathrm{MR}$ in $\mathrm{AH}$ vs. $\mathrm{MUR}$ in $\mathrm{CS}+\mathrm{M}$ in $\mathrm{AH}$ ), where $\mathrm{CS}=$ corn silage diets and $\mathrm{AH}=$ alfalfa hay diets.

${ }^{3} \mathrm{NS}=$ not significant $(P>0.15)$.

${ }^{4} \mathrm{CMCase}=$ carboxymethyl cellulase; activity of enzymes is expressed in units of reducing sugars released per minute of reaction per milligram of protein in particle-associated bacterial samples.

${ }^{5} \mathrm{~A}=$ washout at time $0 ; \mathrm{B}=$ potentially digestible fraction; $\mathrm{C}=$ indigestible fraction; and $\mathrm{K}_{\mathrm{d}}=$ degradation rate of the $\mathrm{B}$ pool. Effective ruminal disappearance $(E R D)=C+B\left[K_{d} /\left(K_{d}+K_{p}\right)\right]$. The passage rate $\left(K_{p}\right)$ was calculated using the equations of Seo et al. (2006) as $K_{p}(\% / h)$ for dry forages $=3.362+0.479 \times(\mathrm{DMI}, \% \mathrm{BW})-0.017(\% \mathrm{NDF}$ of forage $\mathrm{DM})-0.007(\%$ concentrate in diet $\mathrm{DM})$ and $\mathrm{K}_{\mathrm{p}}(\% / \mathrm{h})$ for wet forages $=3.054+0.614 \times(\mathrm{DMI}, \% \mathrm{BW})$.

and corn silage diets had 48 and $39 \%$ NDF, which could have contributed to the reported decrease in nutrient digestibilities through relative differences in maturity. No effect of forage source was noted on the total tract digestibility of NDF in our study. Other authors have reported either a decrease (Hristov and Broderick, 1996) or no change (Broderick, 1985) in NDF digestibility when comparing alfalfa hay to corn silage.

Consistent with the lower concentration of hemicellulose in alfalfa, cattle fed alfalfa hay tended $(P=0.09)$ to be greater for CMCase but lower for xylanase activities than those fed corn silage (Table 7). Alfalfa hay had lower pools of washout NDF $(P=0.08)$ and potentially digestible $\mathrm{NDF}(P<0.01)$, with an increase $(P<$ $0.01)$ in the indigestible pool of NDF. The rate of NDF degradation, however, was greater $(P=0.01)$ for alfalfa hay than corn silage. Reveneau et al. (2005) reported an average rate of degradation $(5.2 \% / \mathrm{h})$ for alfalfa hay that is similar to the current average of $5.3 \% / \mathrm{h}$. Using predicted passage rates using the input data of each cow, there was no difference among treatments in the predicted effective degradability of NDF.

Molasses had no effect on total tract NDF digestibility or CMCase or xylanase activities (Table 7). In contrast,
Huhtanen and Khalili (1992) reported decreased CMCase and xylanase activities in the rumen particulate material when sucrose was fed twice daily compared with ruminal infusion. The $\mathrm{pH}$ of all diets in that study was maintained above 6.0, suggesting that factors other than $\mathrm{pH}$ influenced NDF digestibility or that excess sugars were an alternative substrate for the cellulolytic bacteria. Although dextrose decreased NDF digestibility (Piwonka et al., 1994), a moderate concentration of molasses increased total tract NDF digestibility (Hristov and Ropp, 2003; Broderick and Radloff, 2004). Molasses did not affect the rate of NDF degradation in situ in our study. However, molasses interacted with forage source $(P=0.01)$ by decreasing the potentially digestible pool of NDF in alfalfa hay diets and increasing the potentially digestible pool of NDF in situ in corn silage diets, supporting a carbohydrate effect (Piwonka et al., 1994), at least for the alfalfa diets. Results for NDF digestibility resulting from sugar supplementation are not consistent (Firkins et al., 2008b). Piwonka et al. (1994) observed that ruminal NDF degradation rate in situ increased with dextrose, but particulate passage rate from the rumen also increased, so the opposing effects on digestibility might explain some of the variability. 
Firkins et al. (2008b) discussed the need to prevent N deficiency for ruminal microbes in cows fed sugars to maintain efficacy.

Rumensin tended $(P=0.08)$ to increase CMCase activity (Table 7), which might be expected if gramnegative fiber-degrading bacteria such as Fibrobacter succinogenes produced more cell-associated CMCase than the gram-positive fibrolytics that should be more sensitive to it. Although CMCase is produced by other bacteria that do not degrade polymeric cellulose, we assumed that CMCase reflected a cumulative response to cellulolysis. In support, Prevotella ruminicola increased CMCase considerably when grown on cellobiose than on sucrose (Gardner et al., 1995), and complete degradation of cellulose probably involves a consortium of primary cellulolytic and secondary noncellulolytic bacteria (Wells et al., 1995). Changes in ruminal NDF degradability were proportionately associated with particle-bound CMCase activity (Huhtanen and Khalili, 1992; Piwonka et al., 1994). There was an Rumensin $\times$ forage interaction $(P<0.02)$ for effective ruminal disappearance, resulting from an increase for the corn silage MUR treatment. This treatment had the greatest $\mathrm{pH}$ (Table 6). Monensin might shift fiber digestibility to the intestines but should not decrease total tract NDF digestibility (McGuffey et al., 2001).

\section{FA Biohydrogenation and Digestibility}

In rumen contents, corn silage increased $(P \leq 0.01)$ total conjugated linoleic acid (CLA) isomers, total 18 carbon, total $\mathrm{C}_{18: 1}$, total $\mathrm{C}_{18: 1}$ trans $\mathrm{FA}$, and trans-10, cis-12 CLA (Table 8). Also, corn silage contained more polyunsaturated FA than alfalfa hay ( $54.0 \%$ vs. $48.4 \%$; Table 3). Alfalfa hay decreased $(P<0.01)$ the weight percentage of $\mathrm{C}_{14: 0}$ and $\mathrm{C}_{16: 0} \mathrm{FA}$ as well as the accumulation of trans-10 $\mathrm{C}_{18: 1}$, but alfalfa hay increased $(P$ $=0.01)$ the percentage of $\mathrm{C}_{18: 0}$ (Table 8). Alfalfa hay contains a greater percentage of $\mathrm{C}_{18: 0}$ and $\mathrm{C}_{16: 0}$ (Table 3 ), so the reason for the decrease in $\mathrm{C}_{16: 0} \mathrm{FA}$ is not clear. Although various other intermediates are being discovered and control of biohydrogenation is complex (Ribeiro et al., 2007; Wallace et al., 2007), during the first step of biohydrogenation, most of the $\mathrm{C}_{18: 2 \mathrm{n}-6}$ and $\mathrm{C}_{18: 3 \mathrm{n}-3}$ is being directed toward either the cis-9, trans-11 $\mathrm{C}_{18: 1}$ or trans-10, cis-12 CLA pathways. Increasing grain in the diet or increasing amount of unsaturated fat promotes formation of trans-10 isomers (Jenkins and McGuire, 2006). Ribeiro et al. (2007) reported that sucrose (the major sugar in molasses) did not increase the accumulation of trans- $10 \mathrm{C}_{18: 1}$ intermediates in vitro.

Rumensin tended $(P=0.07)$ to increase trans -10 $\mathrm{C}_{18: 1}$ and increased $(P<0.02)$ trans $-11 \mathrm{C}_{18: 1} \mathrm{FA}$ in rumen contents (Table 8). Treatment did not affect cis-9, trans-11 CLA. The combination of unsaturated fat plus monensin or unsaturated fat plus high grain should also promote accumulation of trans-10 isomers (Bell et al., 2006; Firkins et al., 2006). However, even though butyrate formation (which is common with sugar supplementation) seems to be associated with predominant biohydrogenating bacterial isolates (Paillard et al., 2007), current research (Maia et al., 2007) refutes the prior implication by Firkins et al. (2006) that Megasphaera elsdenii is the major bacterium forming trans-10 isomers. Further work is needed to discern groups of bacteria and regulation of enzymes involved in biohydrogenation, including a potential role for lactate (Maia et al., 2007) if local concentrations in the rumen become high enough to alter biohydrogenation. Even though trans-10 $\mathrm{C}_{18.1}$ does not depress milk fat, it is strongly correlated as an indicator of milk fat depression (Bell et al., 2006; Shingfield et al., 2006). Therefore, greater ruminal concentrations of trans-10 $\mathrm{C}_{18: 1}$ for corn silage $(P<0.05)$ and Rumensin $(P=$ 0.07 ) and particularly for their combination (Rumensin $\times$ forage interaction, $P=0.13$ ) probably elevates the risk for milk fat depression.

Feeding alfalfa hay increased $(P<0.01) \mathrm{C}_{18: 3 \mathrm{n}-3}$ and total $\mathrm{C}_{18: 3}$ FA but decreased $(P=0.02)$ the percentage of medium-chain FA (MCFA, including $\mathrm{C}_{12: 0}$, $\mathrm{C}_{14: 0}, \mathrm{C}_{16: 0}$, and total) in milk (Table 9). Alfalfa hay has greater concentrations of total $\mathrm{C}_{18: 3} \mathrm{FA}$ and MCFA (Table 3), which explains the increase in $\mathrm{C}_{18: 3} \mathrm{FA}$ but not the decrease in MCFA and $\mathrm{C}_{16: 0}$ in the milk of cows fed alfalfa. Perhaps the MCFA were used preferentially for energy or adipose deposition or were just a larger percentage, because alfalfa hay had a numerically lower milk fat yield. Corn silage increased $(P=$ 0.02) trans- $11 \mathrm{C}_{18: 1}$ and total trans $\mathrm{C}_{18: 1}$ compared with cows fed alfalfa hay, probably because corn silage has greater concentrations of unsaturated FA than alfalfa hay (Table 3). Alfalfa hay also had a greater percentage of coarse particles, which should stimulate rumination and potentially influence metabolism by the fibrolytic bacteria that are primarily responsible for biohydrogenation (Maia et al., 2007).

Molasses increased $(P<0.05)$ the trans-10 $\mathrm{C}_{18: 1}$ concentration in milk fat, primarily in corn silage diets, although the $\mathrm{M} \times$ forage interaction term did not approach significance. Because of the urea effect $(P=$ 0.07), which could explain the M effect (MU and MUR vs. control) in corn silage diets, urea, rather than molasses, might have contributed to the increased trans-10 $\mathrm{C}_{18: 1}$. When the cows were fed the corn silage MU and MUR diets, they also had the greatest concentration of total protozoa (see earlier discussion). Protozoa prob- 
Table 8. Least squares means of fatty acid concentrations in rumen contents for dairy cows fed molasses, urea, and monensin with either alfalfa hay or corn silage as a forage source.

\begin{tabular}{|c|c|c|c|c|c|c|c|c|c|c|c|c|c|c|}
\hline \multirow[b]{2}{*}{ Item } & \multicolumn{4}{|c|}{ Corn silage $^{1}$} & \multicolumn{3}{|c|}{ Alfalfa hay ${ }^{1}$} & \multirow[b]{2}{*}{ SEM } & \multicolumn{6}{|c|}{ Contrast $^{2}$} \\
\hline & $\mathrm{C}$ & $\mathrm{M}$ & MU & MUR & $\mathrm{C}$ & M & MR & & $\mathrm{F}$ & M & $\mathrm{M} \times \mathrm{F}$ & $\mathrm{U}$ & $\mathrm{R}$ & $\mathrm{R} \times \mathrm{F}$ \\
\hline Total fat, $\%$ of DM & 6.22 & 5.88 & 6.31 & 5.83 & 6.31 & 6.65 & 6.71 & 0.25 & 0.01 & $\mathrm{NS}^{3}$ & NS & NS & NS & NS \\
\hline \multicolumn{15}{|l|}{ Fatty acid, $\mathrm{g} / 100 \mathrm{~g}$} \\
\hline $\mathrm{C}_{14: 0}$ & 0.67 & 0.65 & 0.72 & 0.67 & 0.62 & 0.58 & 0.56 & 0.03 & $<0.01$ & NS & 0.16 & 0.14 & NS & NS \\
\hline $\mathrm{C}_{16: 0}$ & 17.9 & 17.4 & 18.8 & 18.4 & 18.7 & 17.9 & 17.3 & 0.4 & 0.01 & NS & 0.02 & 0.01 & NS & NS \\
\hline $\mathrm{C}_{18: 0}$ & 29.1 & 28.6 & 27.4 & 24.0 & 32.3 & 29.9 & 29.7 & 1.4 & 0.01 & 0.14 & NS & NS & NS & NS \\
\hline trans $-10 \mathrm{C}_{18: 1}$ & 0.96 & 1.25 & 1.43 & 3.77 & 0.91 & 0.80 & 1.02 & 0.68 & 0.02 & NS & NS & NS & 0.07 & 0.13 \\
\hline trans- $11 \mathrm{C}_{18: 1}$ & 1.92 & 2.10 & 1.96 & 2.68 & 2.20 & 1.98 & 2.61 & 0.28 & NS & NS & NS & NS & 0.02 & NS \\
\hline cis-9 $\mathrm{C}_{18: 1}$ & 8.67 & 8.49 & 9.27 & 9.39 & 7.49 & 7.48 & 7.25 & 0.31 & $<0.01$ & NS & NS & 0.09 & NS & NS \\
\hline cis-9, cis-12 $\mathrm{C}_{18: 2}$ & 24.5 & 22.9 & 26.4 & 25.2 & 18.4 & 19.0 & 16.8 & 1.2 & $<0.01$ & NS & NS & 0.04 & 0.15 & NS \\
\hline trans- 11 , cis- $15 \mathrm{C}_{18: 2}$ & $\mathrm{ND}^{4}$ & ND & ND & ND & ND & ND & ND & & & & & & & \\
\hline cis-9, trans- $11 \mathrm{C}_{18: 2}$ & 0.17 & 0.22 & 0.19 & 0.17 & 0.18 & 0.18 & 0.16 & 0.03 & NS & NS & NS & NS & NS & NS \\
\hline trans-10, cis- $12 \mathrm{C}_{18: 2}$ & 0.15 & 0.17 & 0.19 & 0.18 & 0.11 & 0.10 & 0.10 & 0.02 & $<0.01$ & NS & NS & NS & NS & NS \\
\hline \multicolumn{15}{|l|}{ Summation, g/100 g } \\
\hline Total $\mathrm{C}_{18: 0}$ & 71.8 & 70.3 & 70.7 & 69.2 & 66.4 & 65.3 & 64.8 & 1.1 & $<0.01$ & NS & NS & NS & NS & NS \\
\hline Total $\mathrm{C}_{18: 1}$ & 14.1 & 14.7 & 15.3 & 18.9 & 13.8 & 13.3 & 14.1 & 0.9 & $<0.01$ & NS & NS & NS & 0.02 & 0.11 \\
\hline Total $\mathrm{C}_{18: 3}$ & 0.70 & 0.70 & 0.64 & 0.63 & 0.83 & 0.83 & 0.78 & 0.06 & 0.00 & NS & NS & NS & NS & NS \\
\hline Total CLA ${ }^{5}$ & 0.60 & 0.70 & 0.67 & 0.68 & 0.48 & 0.49 & 0.46 & 0.08 & 0.01 & NS & NS & NS & NS & NS \\
\hline Total trans $\mathrm{C}_{18 \cdot 1}$ & 3.99 & 4.87 & 4.78 & 8.11 & 4.71 & 4.12 & 5.24 & 0.66 & 0.01 & NS & NS & NS & $<0.01$ & 0.09 \\
\hline $\mathrm{SCFA}^{5}$ & 0.58 & 0.61 & 0.56 & 0.57 & 0.60 & 0.59 & 0.49 & 0.04 & NS & NS & NS & NS & NS & 0.14 \\
\hline $\mathrm{MCFA}^{5}$ & 25.7 & 27.0 & 26.7 & 27.9 & 29.6 & 31.0 & 31.6 & 1.2 & $<0.01$ & NS & NS & NS & NS & NS \\
\hline $\mathrm{LCFA}^{5}$ & 2.01 & 2.11 & 2.10 & 2.40 & 3.38 & 3.16 & 3.11 & 0.13 & $<0.01$ & NS & NS & NS & NS & NS \\
\hline
\end{tabular}

${ }^{1} \mathrm{C}=$ control; $\mathrm{M}=$ control plus molasses; $\mathrm{MU}=$ control with molasses and urea; MUR = control with molasses, urea, and Rumensin (Elanco Animal Health, Greenfield, IN); MR $=$ control with molasses and Rumensin. The molasses-containing product also had a blend of corn steep liquor and condensed whey. Rumensin diets provided $16 \mathrm{~g}$ of monensin/909 $\mathrm{kg}$ of DM.

${ }^{2} \mathrm{U}=$ effect of urea (M vs. $\mathrm{MU}$ in $\left.\mathrm{CS}\right) ; \mathrm{M}=$ effect of molasses $(\mathrm{C}$ diets vs. $\mathrm{MU}$ in $\mathrm{CS}+\mathrm{M}$ in $\mathrm{AH}) ; \mathrm{M} \times \mathrm{F}=$ molasses $\times$ forage interaction $(\mathrm{C}$ in $\mathrm{CS}+\mathrm{M}$ in $\mathrm{AH}$ vs. $\mathrm{MU}$ in $\mathrm{CS}+$ $\mathrm{C}$ in $\mathrm{AH}) ; \mathrm{F}=$ effect of forage source $(\mathrm{MU}+\mathrm{MUR}$ in $\mathrm{CS}$ vs. $\mathrm{M}+\mathrm{MR}$ in $\mathrm{AH}) ; \mathrm{R}=$ effect of Rumensin $(\mathrm{MU}$ in $\mathrm{CS}+\mathrm{M}$ in $\mathrm{AH}$ vs. $\mathrm{MUR}$ in $\mathrm{CS}+\mathrm{MR}$ in $\mathrm{AH}) ; \mathrm{R} \times \mathrm{F}=\mathrm{Rumensin}$ $\times$ forage interaction $(\mathrm{MU}$ in $\mathrm{CS}+\mathrm{MR}$ in $\mathrm{AH}$ vs. MUR in $\mathrm{CS}+\mathrm{M}$ in $\mathrm{AH})$, where $\mathrm{CS}=$ corn silage diets and $\mathrm{AH}=$ alfalfa hay diets.

${ }^{3} \mathrm{NS}=$ not significant $(P>0.15)$.

${ }^{4} \mathrm{ND}=$ not detected.

${ }^{5} \mathrm{CLA}=$ conjugated linoleic acid; $\mathrm{SCFA}=$ short-chain fatty acids $\left(\mathrm{C}_{4}\right.$ to $\left.\mathrm{C}_{13}\right) ; \mathrm{MCFA}=$ medium-chain fatty acids $\left(\mathrm{C}_{14}\right.$ to $\left.\mathrm{C}_{17: 1}\right) ; \mathrm{LCFA}=$ long-chain fatty acids $\left(\mathrm{C}_{20}\right.$ to $\left.\mathrm{C}_{22: 6}\right)$. 
Table 9. Least squares means of fatty acid concentrations in milk for dairy cows fed molasses, urea, and monensin with either alfalfa hay or corn silage as a forage source

\begin{tabular}{|c|c|c|c|c|c|c|c|c|c|c|c|c|c|c|}
\hline \multirow[b]{2}{*}{ Item } & \multicolumn{4}{|c|}{ Corn silage $^{1}$} & \multicolumn{3}{|c|}{ Alfalfa hay ${ }^{1}$} & \multirow[b]{2}{*}{ SEM } & \multicolumn{6}{|c|}{ Contrast $^{2}$} \\
\hline & $\mathrm{C}$ & M & $\mathrm{MU}$ & MUR & $\mathrm{C}$ & M & MR & & $\mathrm{F}$ & $\mathrm{M}$ & $\mathrm{M} \times \mathrm{F}$ & $\mathrm{U}$ & $\mathrm{R}$ & $\mathrm{R} \times \mathrm{F}$ \\
\hline \multicolumn{15}{|c|}{ Fatty acid, $\mathrm{g} / 100 \mathrm{~g}$ of total fatty acids } \\
\hline $\mathrm{C}_{4: 0}$ & 3.04 & 3.03 & 3.00 & 2.73 & 3.15 & 3.18 & 2.83 & 0.24 & $\mathrm{NS}^{3}$ & NS & NS & NS & 0.11 & NS \\
\hline $\mathrm{C}_{6: 0}$ & 2.02 & 2.01 & 1.98 & 1.62 & 1.87 & 1.81 & 1.65 & 0.18 & NS & NS & NS & NS & 0.09 & NS \\
\hline $\mathrm{C}_{8: 0}$ & 1.22 & 1.20 & 1.19 & 0.94 & 1.03 & 1.00 & 0.89 & 0.11 & NS & NS & NS & NS & 0.08 & NS \\
\hline $\mathrm{C}_{10: 0}$ & 2.88 & 2.82 & 2.82 & 2.19 & 2.21 & 2.20 & 1.93 & 0.25 & 0.07 & NS & NS & NS & 0.07 & NS \\
\hline $\mathrm{C}_{12: 0}$ & 3.31 & 3.22 & 3.33 & 2.69 & 2.42 & 2.42 & 2.17 & 0.28 & 0.02 & NS & NS & NS & 0.12 & NS \\
\hline $\mathrm{C}_{14: 0}$ & 11.2 & 10.8 & 11.5 & 10.4 & 9.20 & 8.99 & 8.54 & 0.86 & 0.02 & NS & NS & NS & NS & NS \\
\hline $\mathrm{C}_{16: 0}$ & 30.2 & 30.1 & 30.2 & 28.3 & 25.2 & 23.8 & 24.1 & 2.2 & 0.02 & NS & NS & NS & NS & NS \\
\hline $\mathrm{C}_{18: 0}$ & 10.2 & 9.5 & 10.2 & 9.8 & 13.4 & 10.9 & 11.1 & 1.1 & NS & NS & NS & NS & NS & NS \\
\hline trans- $10 \mathrm{C}_{18: 1}$ & 0.36 & 0.40 & 0.60 & 0.55 & 0.43 & 0.49 & 0.46 & 0.07 & NS & 0.05 & NS & 0.07 & NS & NS \\
\hline trans $-11 \mathrm{C}_{18: 1}$ & 2.62 & 2.03 & 3.11 & 6.23 & 2.20 & 2.14 & 2.37 & 0.94 & 0.02 & NS & NS & NS & 0.09 & 0.14 \\
\hline cis-9 $\mathrm{C}_{18.1}$ & 16.4 & 16.0 & 16.6 & 15.9 & 18.7 & 17.7 & 18.1 & 1.7 & NS & NS & NS & NS & NS & NS \\
\hline cis-9, cis-12 $\mathrm{C}_{18: 2}$ & 3.19 & 3.01 & 3.35 & 3.41 & 3.49 & 3.16 & 3.07 & 0.35 & NS & NS & NS & NS & NS & NS \\
\hline trans- 11, cis- $15 \mathrm{C}_{18: 2}$ & 0.13 & 0.14 & 0.15 & 0.17 & 0.04 & 0.04 & 0.05 & 0.03 & $<0.01$ & NS & NS & NS & NS & NS \\
\hline $\mathrm{C}_{18: 3 n-6}$ & 0.05 & 0.04 & 0.05 & 0.03 & 0.04 & 0.05 & 0.04 & 0.01 & NS & NS & NS & NS & 0.01 & NS \\
\hline $\mathrm{C}_{18: 3 \mathrm{n}-3}$ & 0.23 & 0.22 & 0.26 & 0.25 & 0.39 & 0.38 & 0.36 & 0.03 & $<0.01$ & NS & NS & NS & NS & NS \\
\hline cis-9, trans- $11 \mathrm{C}_{18: 2}$ & 0.62 & 0.48 & 0.57 & 0.70 & 0.50 & 0.53 & 0.59 & 0.07 & NS & NS & NS & NS & NS & NS \\
\hline trans -10, cis- $12 \mathrm{C}_{18: 2}$ & $\mathrm{ND}^{4}$ & ND & ND & ND & ND & ND & ND & & & & & & & \\
\hline \multicolumn{15}{|l|}{ Summation } \\
\hline Total $\mathrm{C}_{18: 1}$ & 23.2 & 22.1 & 25.7 & 27.4 & 25.7 & 24.2 & 25.2 & 2.8 & NS & NS & NS & NS & NS & NS \\
\hline Total trans $\mathrm{C}_{18: 1}$ & 5.25 & 4.68 & 7.25 & 10.14 & 5.57 & 5.06 & 5.76 & 1.41 & 0.02 & NS & NS & NS & NS & NS \\
\hline Total $\mathrm{C}_{18: 3}$ & 0.28 & 0.26 & 0.31 & 0.28 & 0.43 & 0.43 & 0.40 & 0.04 & $<0.01$ & NS & NS & NS & NS & NS \\
\hline Total CLA ${ }^{5}$ & 0.62 & 0.50 & 0.60 & 0.72 & 0.51 & 0.54 & 0.60 & 0.07 & NS & NS & NS & NS & NS & NS \\
\hline Total $\mathrm{C}_{18}$ & 38.4 & 36.3 & 41.1 & 42.6 & 44.3 & 39.9 & 41.2 & 4.1 & NS & NS & NS & NS & NS & NS \\
\hline $\mathrm{SCFA}^{5}$ & 13.0 & 12.8 & 12.9 & 10.6 & 11.0 & 11.0 & 9.77 & 1.05 & NS & NS & NS & NS & 0.08 & NS \\
\hline $\mathrm{MCFA}^{5}$ & 45.3 & 44.8 & 46.3 & 42.8 & 37.4 & 35.9 & 35.9 & 3.4 & 0.02 & NS & NS & NS & NS & NS \\
\hline $\mathrm{LCFA}^{5}$ & 0.46 & 0.43 & 0.53 & 0.36 & 0.47 & 0.52 & 0.44 & 0.06 & NS & NS & NS & NS & 0.05 & NS \\
\hline
\end{tabular}

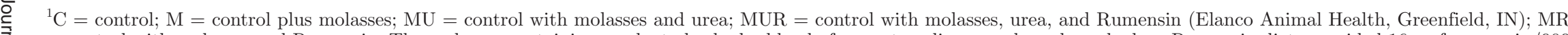
@ = control with molasses and Rumensin. The molasses-containing product also had a blend of corn steep liquor and condensed whey. Rumensin diets provided $16 \mathrm{~g}$ of monensin/909 은 $\mathrm{kg}$ of $\mathrm{DM}$

${ }^{2} \mathrm{U}=$ effect of urea ( $\mathrm{M}$ vs. $\mathrm{MU}$ in $\left.\mathrm{CS}\right) ; \mathrm{M}=$ effect of molasses $(\mathrm{C}$ diets vs. $\mathrm{MU}$ in $\mathrm{CS}+\mathrm{M}$ in $\mathrm{AH}) ; \mathrm{M} \times \mathrm{F}=$ molasses $\times$ forage interaction $(\mathrm{C}$ in $\mathrm{CS}+\mathrm{M}$ in $\mathrm{AH}$ vs. $\mathrm{MU}$ in $\mathrm{CS}+$ $\stackrel{\text { }}{\Sigma}$. $\mathrm{C}$ in $\mathrm{AH}) ; \mathrm{F}=$ effect of forage source $(\mathrm{MU}+\mathrm{MUR}$ in $\mathrm{CS}$ vs. $\mathrm{M}+\mathrm{MR}$ in $\mathrm{AH}) ; \mathrm{R}=$ effect of Rumensin $(\mathrm{MU}$ in $\mathrm{CS}+\mathrm{M}$ in $\mathrm{AH}$ vs. MUR in $\mathrm{CS}+\mathrm{MR}$ in $\mathrm{AH}) ; \mathrm{R} \times \mathrm{F}=\mathrm{Rumensin}$ () $\times$ forage interaction (MU in CS + MR in AH vs. MUR in CS + M in AH), where $\mathrm{CS}=$ corn silage diets and $\mathrm{AH}=$ alfalfa hay diets.

$\stackrel{\circ}{\frac{\Omega}{D}} \quad{ }^{3} \mathrm{NS}=$ not significant $(P>0.15)$.

そ ${ }^{4} \mathrm{ND}=$ not detected. 
ably incorporate unsaturated or partially biohydrogenated FA or even potentially influence populations of biohydrogenating bacteria (Firkins et al., 2008a).

Rumensin tended $(P=0.09)$ to increase the concentration of trans- $11 \mathrm{C}_{18: 1}$, primarily because of a numerical increase in the corn silage MUR treatment (Rumensin $\times$ forage, $P=0.14$ ). Rumensin decreased $(P=0.01)$ the percentage of $\mathrm{C}_{18: 3 \mathrm{n}-6}$ in milk and also tended to decrease $(P<0.10) \mathrm{C}_{6: 0}, \mathrm{C}_{8: 0}, \mathrm{C}_{10: 0}$, and total short-chain FA as well as the very long chain FA. Bell et al. (2006) reported that monensin decreased shortchain FA but only when unsaturated fat was included in the diet. Cows had decreased mammary activities of acetyl coenzyme A carboxylase and FA synthase in high-concentrate diets with unsaturated fats (Piperova et al., 2000), so increased blood supply of biohydrogenation intermediates by cows fed Rumensin apparently caused a metabolic inhibition of de novo FA synthesis in the mammary gland. Rumensin did not change concentrations of cis-9, trans-11 CLA or total CLA. Similar to our results, Bell et al. (2006) reported that trans-10, cis-12 CLA was not detected in milk from cows fed $24 \mathrm{mg} / \mathrm{kg}$ of DM monensin per day. They also reported that Rumensin alone or in combination with unsaturated fat did not change cis-9, trans-11 CLA concentrations. Rumensin did not affect $(P>0.15)$ the percentage of trans-10 $\mathrm{C}_{18: 1}$ in milk even though it was increased in ruminal contents. Nonetheless, the concentration of trans-10 $\mathrm{C}_{18: 1}$ in the rumen could be a useful indicator of milk fat depression (Shingfield et al., 2006).

\section{Lactation Performance}

The main effect means for DMI were not different $(P$ $>0.15)$ for cows fed alfalfa hay vs. corn silage, although milk yield tended $(P=0.10)$ to be lower for alfalfa hay diets (Table 10). The trend for lower milk yield due to forage source is not consistent with previous studies in which no change was observed between corn silage and alfalfa hay (Broderick, 1985; Hristov and Broderick, 1996) or between corn silage and alfalfa silage (Dhiman and Satter, 1997). Cows fed alfalfa hay diets in our study had lower $(P<0.01)$ total tract digestibilities of $\mathrm{DM}$, OM, and $\mathrm{N}$ than did those fed corn silage (Table 7), which, combined with the trend for lower DMI, explained the trend for lower milk yields. A lower lactose percentage (Table 10) supports the conclusion that a lower intake of digestible carbohydrate limited milk production for cows fed alfalfa hay compared with corn silage in the current study.

No main effects or interactions of molasses on DMI were detected. Broderick and Radloff (2004) reported an increase in DMI when liquid molasses was supple-

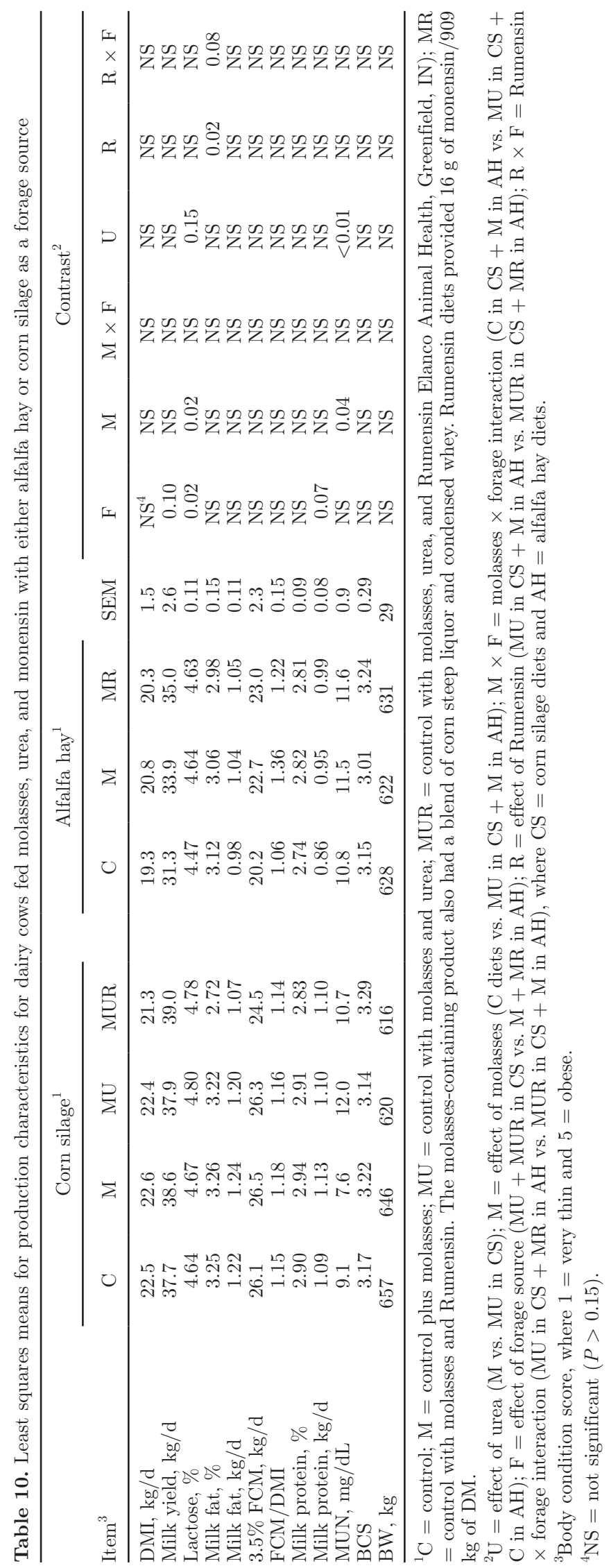


mented at the rate of $3 \%$ of the diet DM (equivalent to $4.9 \%$ total sugars). However, when molasses increased total dietary sugars to up to $7.4 \%$, DMI was not different from the control diet. Our inclusion rate of molasses was $2.6 \%$, with an average measured value of $7.6 \%$ total sugars in the molasses diets. When a liquid feed containing molasses was added, DMI was enhanced only when diets were formulated with decreasing NFC concentration to maintain rumen fermentability (Firkins et al., 2008b). Molasses increased lactose percentage but did not increase milk production.

The main effect means for DMI and efficiency of FCM production did not change $(P>0.15)$ with addition of Rumensin to the diets. This agrees with some reports that Rumensin might not decrease DMI in lactating dairy cows, whereas trends for slightly decreasing DMI and improving efficiency are common (Ipharraguerre and Clark, 2003). Sauer et al. (1989) also reported an increase in milk production efficiency and observed both an increase in milk production and a decrease in DMI as Rumensin was increased from 6 to $24 \mathrm{mg} /$ $\mathrm{kg}$ of DM per day, although Phipps et al. (2000) did not note such a dose response on DMI. Most likely, an improvement in FCM and DMI would not occur if milk fat was depressed and might take a longer time for a true evaluation of efficacy than $4 \mathrm{wk}$, particularly with consideration toward BW gain.

Rumensin decreased milk fat percentage more in corn silage than alfalfa hay diets (Rumensin $\times$ forage interaction, $P<0.08$; Table 10). However, there was no change in milk fat yield, because there were numerical increases in milk volume. Krause and Combs (2003) reported that high-moisture corn decreased milk fat percentage compared with dry ground corn, apparently because of the greater ruminal NSC digestibility of the high-moisture corn. However, dry ground corn only depressed milk fat percentage when corn silage was added to the forage. Rumensin has been noted to decrease milk fat percentage in diets with high grain concentrations or with unsaturated fats (Bell et al., 2006; Firkins et al., 2006). The current diets contained about $18 \%$ forage NDF and contained similar amounts of unsaturated fats in all diets (Tables 1 to 3 ). Our results are supported by those of Sauer et al. (1989) and Phipps et al. (2000), both of whom observed a decrease in milk fat percentage, but not yield, when feeding Rumensin in diets with a 50:50 or 60:40 forage-to-concentrate ratio, respectively. However, when molasses was added while maintaining rumen-degraded carbohydrate concentration by decreasing NFC, Rumensin did not depress milk fat percentage or yield, even with $6.5 \%$ liquid feed (Firkins et al., 2008b).

Milk protein percentage was not affected by treatment, but milk protein yield tended to decrease $(P=$
0.07) with alfalfa hay diets (Table 10). Broderick (1985) reported that alfalfa hay decreased milk protein percentage and yield in comparison to corn silage. As discussed previously, cows fed alfalfa hay had numerically lower DMI and statistically lower OM digestibility. Lower $\mathrm{NE}_{\mathrm{L}}$ intake could have resulted in more AA being used for glucose equivalents than for protein synthesis in the mammary gland (Shingfield et al., 2006).

Urea addition to the corn silage diets increased $(P$ $<0.01$ ) MUN concentration (Table 10) because of the increase $(P<0.01)$ in $\mathrm{CP}$ concentration (Table 2 ) and resultant ruminal $\mathrm{NH}_{3}-\mathrm{N}$ concentration from urea addition (Table 6). Crude protein concentration has been positively correlated to BUN concentration, which equilibrates rapidly throughout body fluids, including milk (Kohn et al., 2002). Because the molasses comparison is for corn silage C vs. MU + MUR and alfalfa hay $\mathrm{C}$ vs. $\mathrm{M}+\mathrm{MR}$, the effect of urea addition is included. The MUN for corn silage M was below targets for optimal protein availability in dairy cattle (Kohn et al., 2002). Although cows fed alfalfa hay diets with $\mathrm{M}$ and $\mathrm{MR}$ had lower ruminal $\mathrm{NH}_{3}-\mathrm{N}$ concentrations than did those fed the corn silage MU plus MUR diets (Table 6), there was no effect on milk MUN. Although not widely researched, perhaps a greater proportion of $\mathrm{NH}_{3}-\mathrm{N}$ was from transfer of BUN into the rumen for those fed alfalfa hay diets.

\section{CONCLUSIONS}

Despite minor changes in fermentation characteristics, molasses supplementation increased the distribution of the protozoal family Diplodiniinae when cows were fed diets with alfalfa hay but not corn silage, but only without Rumensin. Regardless of forage source, Rumensin decreased the concentration of short-chain FA in milk. No increase in trans-10, cis-12 CLA was detected in milk fat, although Rumensin did increase trans-10 $\mathrm{C}_{18: 1}$ concentrations in rumen contents, and this tended to be greater for corn silage vs. alfalfa hay. In diets already with low-forage NDF (18\%), the proportion of larger particles in the hay diets or perhaps a relatively lower quality compared with corn silage might have influenced our results. The lack of molasses $\times$ forage interactions supports a minor effect of molasses on biohydrogenation. Moreover, molasses shifted the proportion of particles from the pan to the middle screen for corn silage diets. With consideration of ruminal $\mathrm{N}$ availability and MUN, molasses is a highly digestible feed source that might improve TMR consistency for dairy cattle, particularly if carbohydrate fermentability is tempered by decreasing NFC concentration in the diet. If Rumensin is added to diets with a high amount of corn silage, attention should be given to the amount 
of unsaturated fat and the ruminal carbohydrate digestibility to avoid potential milk fat depression.

\section{ACKNOWLEDGMENTS}

We express our sincere appreciation to Andy Spring and the Waterman farm crew for the care and milking of the cows, to Denise Pfefferle (The Ohio State University) for her help with feeding, and to fellow students for their help in analyzing samples. The authors would like to particularly thank Claudio Ribeiro (The Ohio State University) for his help with FA analysis.

\section{REFERENCES}

AOAC. 1990. Official Methods of Analysis. 15th ed. AOAC Int., Arlington, VA.

Bell, J. A., J. M. Griinari, and J. J. Kennelly. 2006. Effect of safflower oil, flaxseed oil, monensin, and vitamin $\mathrm{E}$ on concentration of conjugated linoleic acid in bovine milk fat. J. Dairy Sci. 89:733748 .

Béra-Maillet, C., E. Devillard, M. Cezette, J. P. Jouany, and E. Forano. 2005. Xylanases and carboxymethylcellulases of the rumen protozoa Polyplastron multivesiculatum, Eudiplodinium maggii and Entodinium sp. FEMS Microbiol. Lett. 244:149-156.

Broderick, G. A. 1985. Alfalfa silage or hay versus corn silage as the sole forage for lactating dairy cows. J. Dairy Sci. 68:3262-3271.

Broderick, G. A., and W. J. Radloff. 2004. Effect of molasses supplementation on the production of lactating dairy cows fed diets based on alfalfa and corn silage. J. Dairy Sci. 87:2997-3009.

Brossard, L., C. Martin, F. Chaucheyras-Durand, and B. MichaletDoreau. 2004. Protozoa involved in butyric rather than lactic fermentative pattern during latent acidosis in sheep. Reprod. Nutr. Dev. 44:195-206.

Chaney, A. L., and E. P. Marbach. 1962. Modified reagents for determination of urea and ammonia. Clin. Chem. 8:130-132.

DeFrain, J. M., A. R. Hippen, K. F. Kalscheur, and D. J. Schingoethe. 2004. Feeding lactose increases ruminal butyrate and plasma $\beta$-hydroxybutyrate in lactating dairy cows. J. Dairy Sci. 87:24862494.

DeFrain, J. M., A. R. Hippen, K. F. Kalscheur, and D. J. Schingoethe. 2006. Feeding lactose to increase ruminal butyrate and the metabolic status of transition dairy cows. J. Dairy Sci. 89:267276 .

Dehority, B. A. 2003. Rumen Microbiology. Nottingham University Press, Nottingham, UK

Dennis, S. M., M. J. Arambel, E. E. Bartley, and A. D. Dayton. 1983. Effect of energy concentration and source of nitrogen on numbers and types of rumen protozoa. J. Dairy Sci. 66:1248-1254.

Dennis, S. M., T. G. Nagaraja, and A. D. Dayton. 1986. Effect of lasalocid, monensin and thiopeptin on rumen protozoa. Res. Vet. Sci. 41:251-256.

DeVries, T. J., K. A. Beauchemin, and M. A. G. von Keyserlingk. 2007. Dietary forage concentration affects the feed sorting behavior of lactating dairy cows. J. Dairy Sci. 90:5572-5579.

Dhiman, T. R., and L. D. Satter. 1997. Yield response of dairy cows fed different proportions of alfalfa silage and corn silage. J. Dairy Sci. 80:2069-2082

Firkins, J. L., M. L. Eastridge, N. R. St-Pierre, and S. M. Noftsger. 2001. Effects of grain variability and processing on starch utilization by lactating dairy cattle. J. Anim. Sci. 79(E. Suppl.):E218-E238.

Firkins, J. L., A. N. Hristov, M. B. Hall, G. A. Varga, and N. R. StPierre. 2006. Integration of ruminal metabolism in dairy cattle. J. Dairy Sci. 89(E. Suppl.):E31-E51.

Firkins, J. L., S. K. R. Karnati, and Z. Yu. 2008a. Linking rumen function to animal response by application of genomic function. Aust. J. Anim. Prod. 48:711-721.
Firkins, J. L., B. S. Oldick, J. Pantoja, L. E. Gilligan, and L. Carver. 2008b. Efficacy of liquid feeds varying in concentration and composition of fat, non-protein nitrogen, and non-fiber carbohydrates for lactating dairy cows. J. Dairy Sci. 91:19691984.

Firkins, J. L., Z. Yu, and M. Morrison. 2007. Ruminal nitrogen metabolism: Perspectives for integration of microbiology and nutrition for dairy. J. Dairy Sci. 90(E. Suppl.):E1-E16.

Gardner, R. G., J. E. Wells, J. B. Russell, and D. B. Wilson. 1995. The cellular location of Prevotella ruminicola $\beta$-1,4-D-endoglucanase and its occurrence in other strains of ruminal bacteria. Appl. Environ. Microbiol. 61:3288-3292.

Harvatine, D. I., J. L. Firkins, and M. L. Eastridge. 2002. Whole linted cottonseed as a forage substitute fed with ground or steam-flaked corn: Digestibility and performance. J. Dairy Sci. 85:1976-1987.

Hristov, A. N., and G. A. Broderick. 1996. Synthesis of microbial protein in ruminally cannulated cows fed alfalfa silage, alfalfa hay, or corn silage. J. Dairy Sci. 79:1627-1637.

Hristov, A. N., and J. K. Ropp. 2003. Effect of dietary carbohydrate composition and availability on utilization of ruminal ammonia nitrogen for milk protein synthesis in dairy cows. J. Dairy Sci. $86: 2416-2427$

Huhtanen, P., and H. Khalili. 1992. The effect of sucrose supplements on particle-associated carboxymethylcellulase (EC 3.2.1.4) and xylanase (EC 3.2.1.8) activities in cattle given grass-silage-based diet. Br. J. Nutr. 67:245-255.

Ipharraguerre, I. R., and J. H. Clark. 2003. Usefulness of ionophores for lactating dairy cows: A review. Anim. Feed Sci. Technol. 106:39-57.

Jenkins, T. C., and M. A. McGuire. 2006. Major advances in nutrition: Impact of milk composition. J. Dairy Sci. 89:1302-1310.

Kohn, R. A.. K. F. Kalscheur, and E. Russek-Cohen. 2002. Evaluation of models to estimate urinary nitrogen and expected milk urea nitrogen. J. Dairy Sci. 85:227-233.

Krause, K. M., and D. K. Combs. 2003. Effects of forage particle size, forage source, and grain fermentability on performance and ruminal $\mathrm{pH}$ in midlactation cows. J. Dairy Sci. 86:1382-1397.

Leonardi, C., and L. E. Armentano. 2003. Effect of quantity, quality, and length of alfalfa hay on selective consumption by dairy cows. J. Dairy Sci. 86:557-564.

Maia, M. R. G., L. C. Chaudhary, L. Figeres, and R. J. Wallace. 2007. Metabolism of polyunsaturated fatty acids and their toxicity to the microflora of the rumen. Antonie Van Leeuwenhoek 91:303-314.

McGuffey, R. K., L. F. Richardson, and J. I. D. Wilkinson. 2001 Ionophores for dairy cattle: Current status and future outlook. J. Dairy Sci. 84(E. Suppl.):E194-E203.

Murphy, M. R., and J. S. Zhu. 1997. A comparison of methods to analyze particle size as applied to alfalfa haylage, corn silage, and concentrate mix. J. Dairy Sci. 80:2932-2938.

Nagaraja, T. G., and E. C. Titgemeyer. 2007. Ruminal acidosis in beef cattle: The current microbiological and nutritional outlook. J. Dairy Sci. 90(E. Suppl.):E17-E38.

Newbold, C. J., N. R. McEwan, R. E. Calza, E. N. Chareyron, S. M. Duval, S. C. Eschenlauer, F. M. McIntosh, N. Nelson, A. J. Travis, and R. J. Wallace. 2005. An $\mathrm{NAD}^{+}$-dependent glutamate dehydrogenase cloned from the ruminal ciliate protozoan, Entodinium caudatum. FEMS Microbiol. Lett. 247:113-121.

NRC. 2001. Nutrient Requirements of Dairy Cattle. 7th rev. ed. National Academy Press, Washington, DC.

Paillard, D., N. McKain, L. C. Chaudhary, N. D. Walker, F. Pizette, I. Koppova, N. R. McEwan, J. Kopecny, P. E. Vercoe, P. Louis, and R. J. Wallace. 2007. Relation between phylogenetic position, lipid metabolism and butyrate production by different Butyrivibrio-like bacteria from the rumen. Antonie Van Leeuwenhoek 91:417422.

Palmquist, D. L., and T. C. Jenkins. 2003. Challenges with fats and fatty acid methods. J. Anim. Sci. 81:3250-3254.

Phipps, R. H., J. I. Wilkinson, L. J. Jonker, M. Tarrant, A. K. Jones, and A. Hodge. 2000. Effect of monensin on milk production of Holstein-Friesian dairy cows. J. Dairy Sci. 83:2789-2794. 
Piperova, L. S., B. B. Teter, I. Bruckental, J. Sampugna, S. E. Mills, M. P. Yurawecz, J. Fritsche, K. Ku, and R. A. Erdman. 2000. Mammary lipogenic enzyme activity, trans fatty acids and conjugated linoleic acids are altered in lactating dairy cows fed a milk fat-depressing diet. J. Nutr. 130:2568-2574.

Piwonka, E. J., J. L. Firkins, and B. L. Hull. 1994. Digestion in the rumen and total tract of forage-based diets with starch or dextrose supplements fed to Holstein heifers. J. Dairy Sci. 77:1570-1579.

Reveneau, C., S. E. Adams, M. A. Cotta, and M. Morrison. 2003. Phenylacetic and phenylpropionic acids do not affect xylan degradation by Ruminococcus albus. Appl. Environ. Microbiol. 69:6954-6958.

Reveneau, C., C. V. Ribeiro, M. L. Eastridge, N. R. St-Pierre, and J L. Firkins. 2005. Processing whole cottonseed moderates fatty acid metabolism and improves performance by dairy cows. J. Dairy Sci. 88:4342-4355.

Ribeiro, C. V. D. M., M. L. Eastridge, J. L. Firkins, N. R. St-Pierre, and D. L. Palmquist. 2007. Kinetics of fatty acid biohydrogenation in vitro. J. Dairy Sci. 90:1405-1416.

Russell, J. B. 1998. Strategies that ruminal bacteria use to handle excess carbohydrate. J. Anim. Sci. 76:1955-1963.

Sauer, F. D., J. K. Kramer, and W. J. Cantwell. 1989. Antiketogenic effects of monensin in early lactation. J. Dairy Sci. 72:436-442.

Seo, S., L. O. Tedeschi, C. G. Schwab, B. D. Garthwaite, and D. G. Fox. 2006. Evaluation of the passage rate equations in the 2001 Dairy NRC model. J. Dairy Sci. 89:2327-2342.

Shingfield, K. J., C. K. Reynolds, G. Hervás, J. M. Griinari, A. S. Grandison, and D. E. Beever. 2006. Examination of the persistency of milk fatty acid composition responses to fish oil and sunflower oil in the diet of dairy cows. J. Dairy Sci. 89:714-732.

Sylvester, J. T., S. K. R. Karnati, B. A. Dehority, M. Morrison, G. L. Smith, N. R. St-Pierre, and J. L. Firkins. 2009. Rumen protozoa decrease generation time and adjust $18 \mathrm{~S}$ ribosomal DNA copies to adapt to decreased transfer interval, starvation, and monensin. J. Dairy Sci. 92:256-269.

Tafaj, M., Q. Zebeli, C. Baes, H. Steingass, and W. Drochner. 2007. A meta-analysis examining effects of particle size of total mixed rations on intake, rumen digestion and milk production in highyielding dairy cows in early lactation. Anim. Feed Sci. Technol. 138:137-161

Van Soest, P. J., J. B. Robertson, and B. A. Lewis. 1991. Methods for dietary fiber, neutral detergent fiber, and nonstarch polysaccharides in relation to animal nutrition. J. Dairy Sci. 74:3583-3597.

Wallace, R. J., N. McKain, K. J. Shingfield, and E. Devillard. 2007. Isomers of conjugated linoleic acids are synthesized via different mechanisms in ruminal digesta and bacteria. J. Lipid Res. 48:2247-2254.

Wells, J. E., J. B. Russell, Y. Shi, and P. J. Weimer. 1995. Cellodextrin efflux by the cellulolytic ruminal bacterium fibrobacter succinogenes and its potential role in the growth of nonadherent bacteria. Appl. Environ. Microbiol. 61:1757-1762.

Williams, A. G., and G. S. Coleman. 1992. The Rumen Protozoa. Springer-Verlag, New York, NY.

Williams, C. H., D. J. David, and O. Iismaa. 1962. The determination of chromic oxide in faeces samples by atomic absorption spectrophotometry. J. Agric. Sci. 59:381-385. 